\title{
ESTIMATING AN ORIGIN-DESTINATION TABLE FOR U.S. IMPORTS OF WATERBORNE CONTAINERIZED FREIGHT
}

\author{
A Thesis \\ Presented to the Faculty of the Graduate School \\ of Cornell University \\ In Partial Fulfillment of the Requirements for the Degree of \\ Master of Science
}

by

Brian Seth Levine

January 2008 
(C) 2008 Brian Seth Levine 


\begin{abstract}
U.S. imports of containerized freight have been growing at about $10 \%$ per year over the past decade and now exceed 18.5 million TEUs (twenty-foot equivalent units) per year. Container traffic is highly concentrated at a small number of ports, with approximately $88 \%$ of total containerized imports (measured in TEUs) entering through the 10 largest ports. Clearly, waterborne containerized imports are of vital economic concern to the United States. Given the growth rate of imports experienced at U.S. container ports, the concentration of traffic at a small number of sea ports, and the vulnerability of some of these seaports to natural hazards, it is important to have an accurate understanding of the flow of containers from their origin country through U.S. seaports to their final destination in the United States, so that investments in port capacity and other transportation infrastructure can be made consistent with the needs generated by this traffic. This paper develops an optimization model to synthesize the PIERS international trade data, the Carload Waybill data available from the Surface Transportation Board, and economic data into an estimate of an origin-destination table for the number of containers (measured in TEUs) that are shipped from foreign countries to aggregations of Bureau of Economic Analysis (BEA) economic areas in the United States.
\end{abstract}




\section{BIOGRAPHICAL SKETCH}

Brian Levine was born and raised in Brooklyn, NY. He attended Stuyvesant High School in New York City and then enrolled in Cornell University for his undergraduate studies. In 2005, he received his bachelor's degree in Civil \& Environmental Engineering and graduated magna cum laude with honors. His research interests include using mathematical models to understand the behavior of transportation systems, specifically related to airlines. Currently, he is supported by a Department of Energy Computational Science Graduate Fellowship and plans to continue at Cornell University for his Ph.D. and pursue further research in this field. 


\section{ACKNOWLEDGMENTS}

I would like to acknowledge the continued support of my committee chair and advisor, Linda K. Nozick. Her dedication to students never goes unnoticed. I would also like to thank all of my other professors at Cornell University for their teaching and guidance over the years. 
TABLE OF CONTENTS

BIOGRAPHICAL SKETCH

ACKNOWLEDGEMENTS $\quad$ iv

LIST OF FIGURES vi vi vis

LIST OF TABLES vii

LIST OF ABBREVIATIONS viii

CHAPTER 1: INTRODUCTION 1

CHAPTER 2: MODEL FORMULATION 5

CHAPTER 3: INSIGHTS FROM THE MODEL 22

CHAPTER 4: CONCLUSIONS AND FUTURE RESEARCH 32

$\begin{array}{ll}\text { APPENDIX } & 34\end{array}$

$\begin{array}{ll}\text { REFERENCES } & 48\end{array}$ 


\section{LIST OF FIGURES}

Figure 1. Containers Imported from 1997 to 2006

Figure 2. Waterborne Containerized Imports from Select Countries 2

$\begin{array}{lr}\text { Figure 3. Origin Countries } & 6\end{array}$

Figure 4. Transportation Analysis Zones $\quad 7$

Figure 5. Sample Routes in the Network 8

Figure 6. Flows from Selected Ports to TAZs based on 2003 STB Waybill 12

Figure 7. Export Port Volumes from China $\quad 24$

Figure 8. U.S. Port Volumes from China 24

Figure 9. Estimated Number of TEUs Imported from China to TAZs 26

Figure 10. Flow of Containers from Key West Coast Ports to TAZs 27

Figure 11. Flow of Containers from Key East Coast Ports to TAZs 27

Figure 12. Inferred Flows from West Coast Ports through Chicago \& Memphis 29

Figure 13. Distribution of TEUs Across Regions of Origin for each TAZ 29 


\section{LIST OF TABLES}

Table 1. Estimated Container Originations by Port 10

Table 2. Discrepancies in Model Results with 2003 STB Waybill 22 


\section{LIST OF ABBREVIATIONS}

BEA: Bureau of Economic Analysis

GDP: Gross Domestic Product

PIERS: Port Import Export Reporting Service

STB: Surface Transportation Board

TAZ: Transportation Analysis Zone

TEU: Twenty-foot equivalent containers 


\section{CHAPTER 1}

\section{INTRODUCTION}

In 2006, almost 18.5 million twenty-foot equivalent units (TEUs) of goods entered the United States through U.S. container ports (U.S. Maritime Administration, 2007). On average, containerized import volumes have been growing at about $10 \%$ per year over the last decade. Figure 1 gives the total number of containers (in TEUs) imported, as well as the number that entered through the 4 largest container ports from 1997 to 2006. In 2006, approximately 23\% of containers entered through the port of Los Angeles, which has experienced a growth rate of about $14 \%$ per year over the last decade. The second largest container port is Long Beach, which handled about 20\% of imported containers in 2006 and has been experiencing a growth rate of about 20\% per year over the last decade. It is clear from the figure that container traffic is highly concentrated at a small number of ports. Almost $88 \%$ of total containerized imports (measured in TEUs) enter through the 10 largest ports. These ports are Los Angeles, Long Beach, New York, Charleston, Savannah, Norfolk, Oakland, Seattle, Tacoma, and Houston.

Figure 2 gives the number of containers imported into the U.S. in 1997, 2000, 2003 and 2006 from the 10 largest importing countries (U.S. Maritime Administration, 2007). China is the largest, representing over 45\% of containers imported in 2006 and experiencing more than a $20 \%$ annual growth rate over the last decade. 


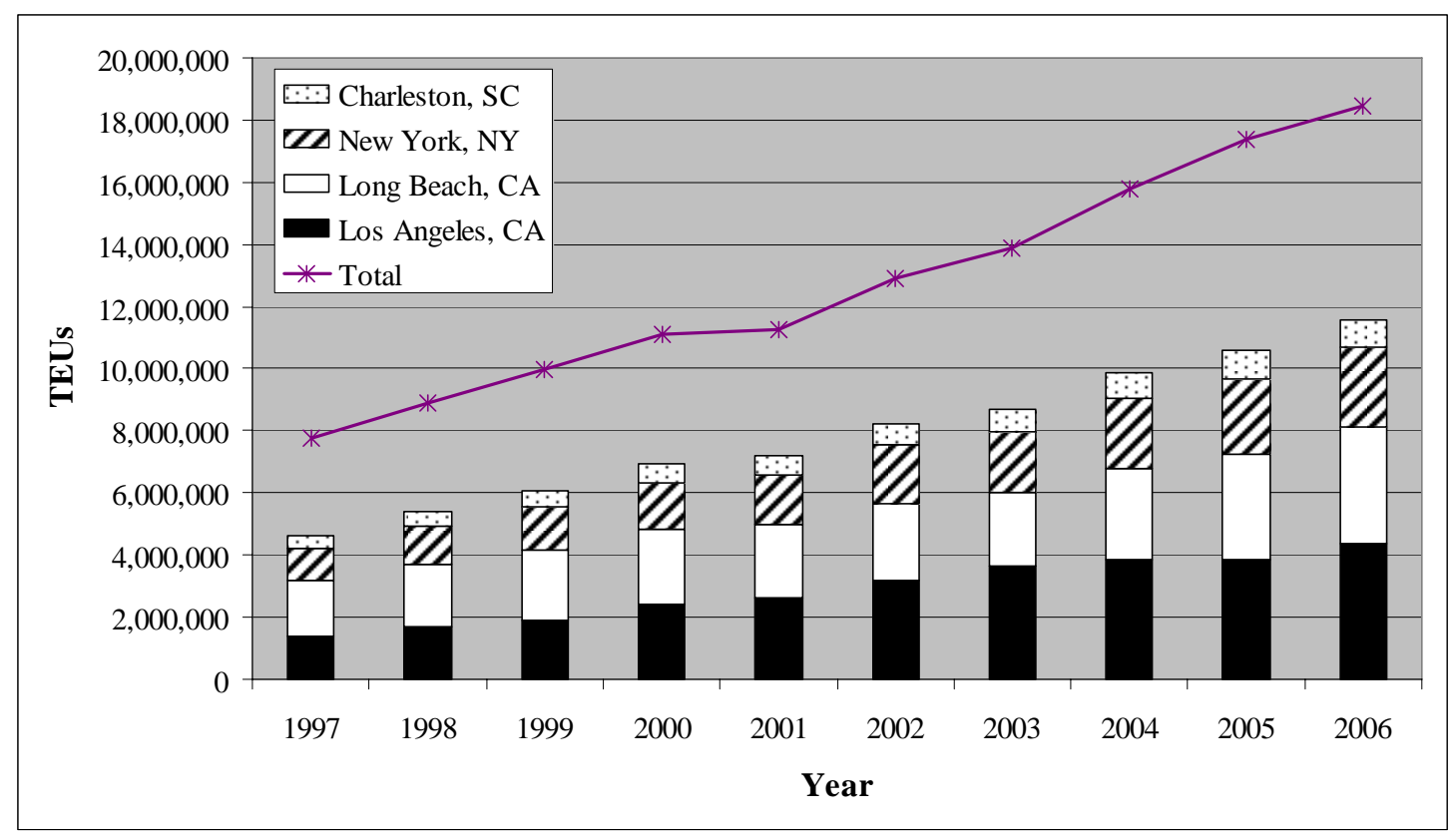

Figure 1. Containers (measured in TEUs) Imported from 1997 to 2006

(U.S. Maritime Administration, 2007)

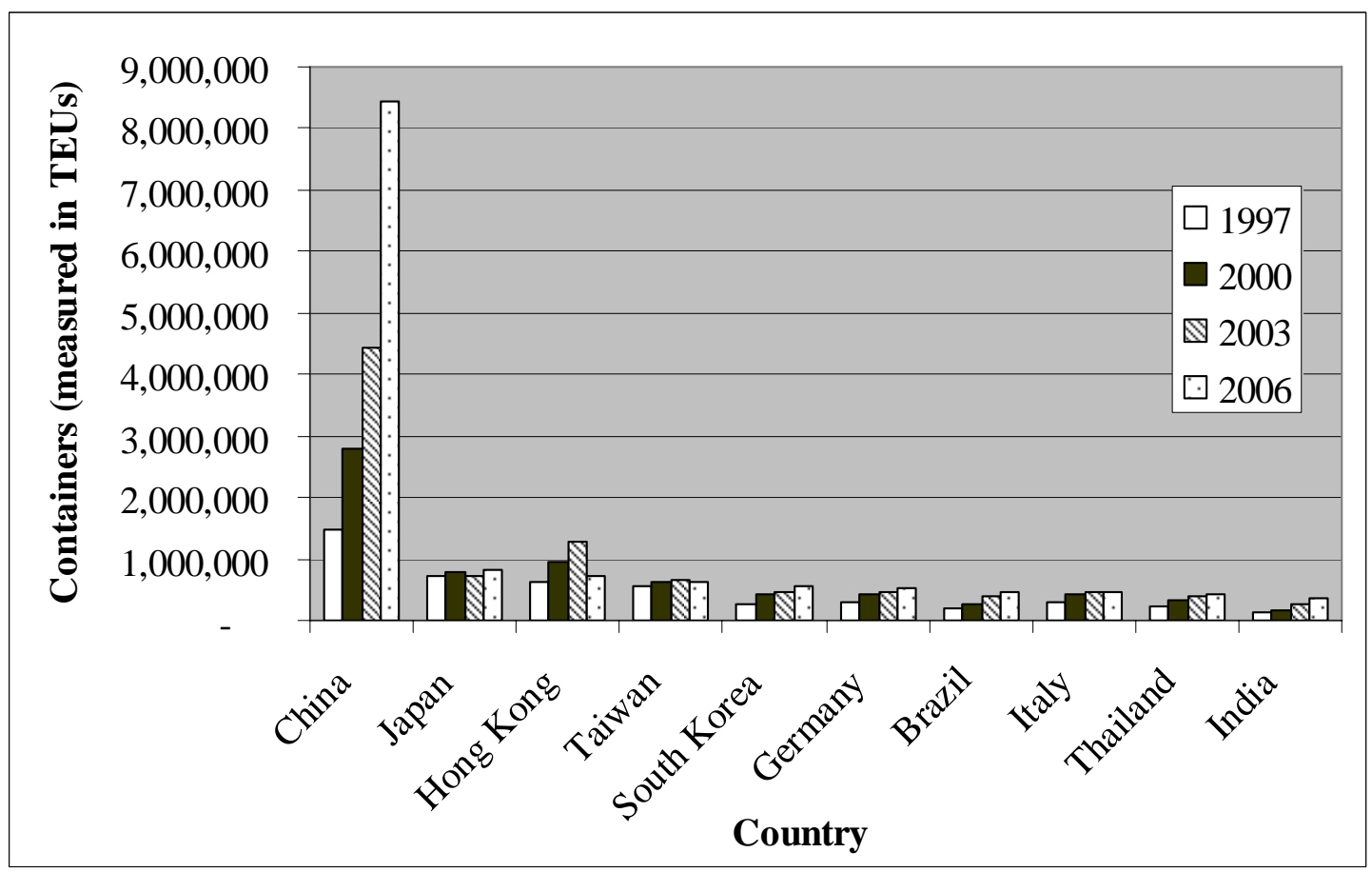

Figure 2. Waterborne Containerized Imports from Select Countries

(U.S. Maritime Administration, 2007) 
These waterborne containerized imports are worth over 30 trillion dollars in value and represent commodities such as furniture, electronics, machinery, toys and games, and beverages (Waterborne Databank, 2004). Clearly, these imports are of vital economic concern to the United States. Also, several container ports are in areas threatened by natural disasters. During the 1989 Loma Prieta earthquake in the San Francisco Bay Area, the Port of Oakland sustained significant damage from earthquake induced settlement and liquefaction resulting in damage to rail lines, cranes, and cracked wharf piles. Given the growth rate of imports experienced at U.S. container ports, the concentration of traffic at a small number of sea ports, and the vulnerability of some of these seaports to natural hazards, it is important to have an accurate understanding of the flow of containers from their origin country through U.S. seaports to their final destination in the United States, so that investments in port capacity and other transportation infrastructure can be made consistent with the needs generated by this traffic.

This paper focuses on the estimation of the number of containers (measured in TEUs) that are shipped from foreign countries through international and U.S. ports to aggregations of Bureau of Economic Analysis (BEA) economic areas in the United States. BEA areas are geographic regions, denoted by a collection of counties, which represent centers of regional economic activity. There are 177 of these regions in the United States. While there is considerable data related to containerized shipments, no origin-destination table of this nature currently exists. To estimate the origindestination table, we have developed an optimization model that synthesizes data on international trade available from PIERS Global Intelligence Solutions and the Carload Waybill Sample of domestic railcar movements available from the Surface 
Transportation Board (STB) with a gravity model of the demand for the transportation of international sea containers.

The next chapter focuses on the development of an optimization model to estimate an origin-destination model for containerized traffic. The third chapter describes the insights gained from the application of that model to U.S. waterborne containerized imports for 2004. The fourth chapter discusses conclusions and opportunities for future research. 


\section{CHAPTER 2}

\section{MODEL FORMULATION}

We formulate the origin-destination table estimation problem as a linear program where the origins are one of 67 foreign countries and the destinations are aggregations of BEA economic areas which form 84 regions. As mentioned previously, we integrate two types of data into the optimization: the PIERS dataset on international trade from 2004 and the Carload Waybill sample of domestic railcar movements from 2003. We also integrate a gravity model into the mathematical formulation. The goal is to synthesize an origin-destination table that matches the datasets and the gravity model as closely as possible.

Figure 3 presents a map of the 67 countries that are considered container origins and a graphical representation of the number of containers they export to the U.S. These 67 countries represent about $98 \%$ of the containers that entered the U.S. in 2004. In Figure 3, the container volumes for China and Hong Kong have been grouped together (though not in the model) and represent more than 39\% and 7\% of containers imported (as measured in TEU sea containers) in 2004, respectively. From this map, it is clear that the largest export countries can be grouped into three distinct regions: Asia, Europe, and Central \& South America. Asia represents $72 \%$ of the exports with almost 11 million TEUs, Europe represents $16.9 \%$ with approximately 2.5 million TEUs, while Central \& South America only represent $11.1 \%$ with 1.67 million TEUs. 


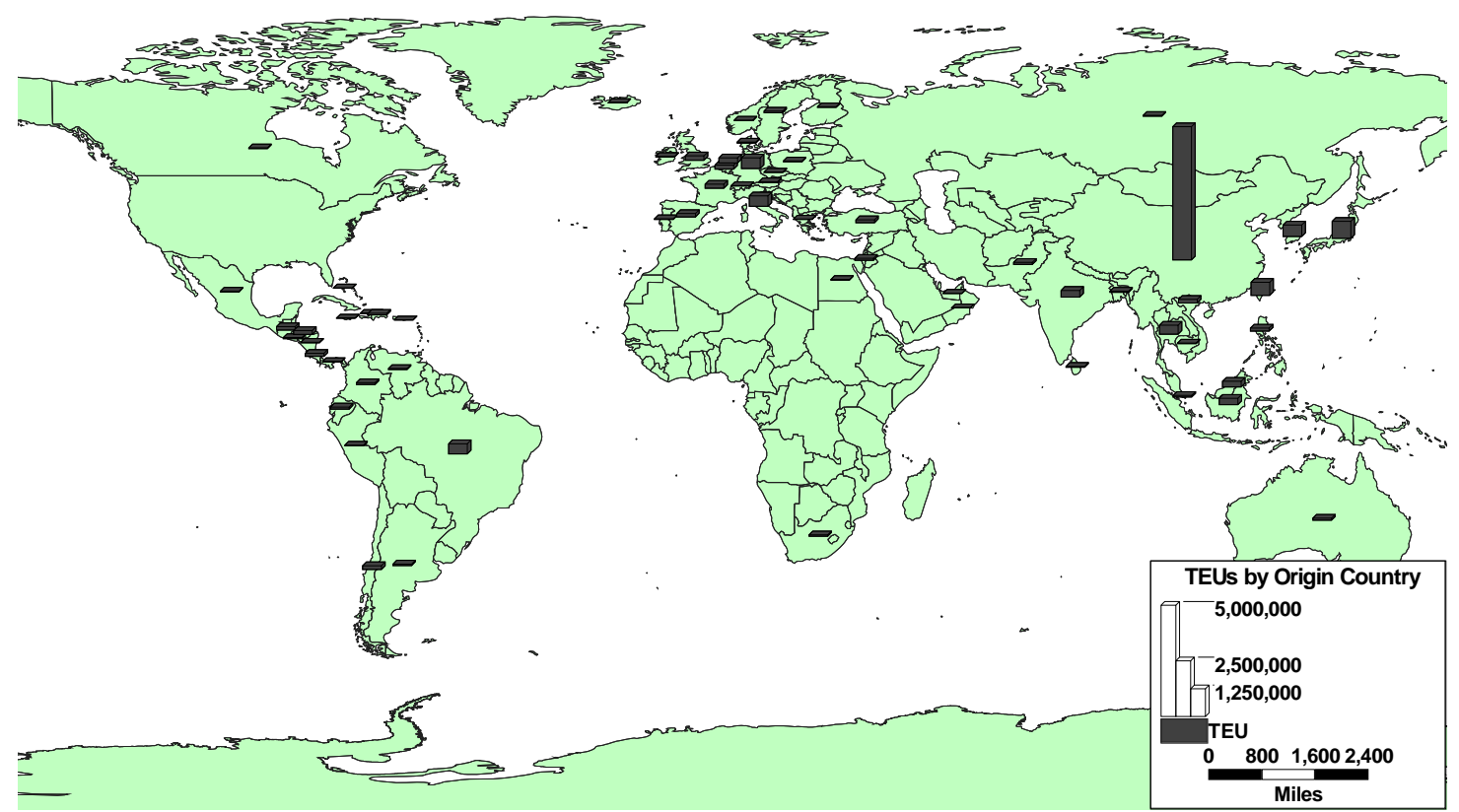

Figure 3. Origin Countries

The 84 regions we refer to as Transportation Analysis Zones (TAZs) are illustrated in Figure 4 and cover the entire continental U.S. Each TAZ is composed of one or more BEA economic areas. The BEA economic areas are indicated by the dashed lines in the figure. For example, TAZ 152 is composed of BEA Economic areas 110 through 113. Since the countries are considered the origins and the TAZs are the destinations, the number of loaded containers to be moved (over some defined period of time) can be summarized by a 67 x 84 table. For this analysis, we use the 2004 PIERS international trade-data, the 2003 STB Waybill, and economic data from 2004; hence, the estimated origin-destination table is for 2004. 


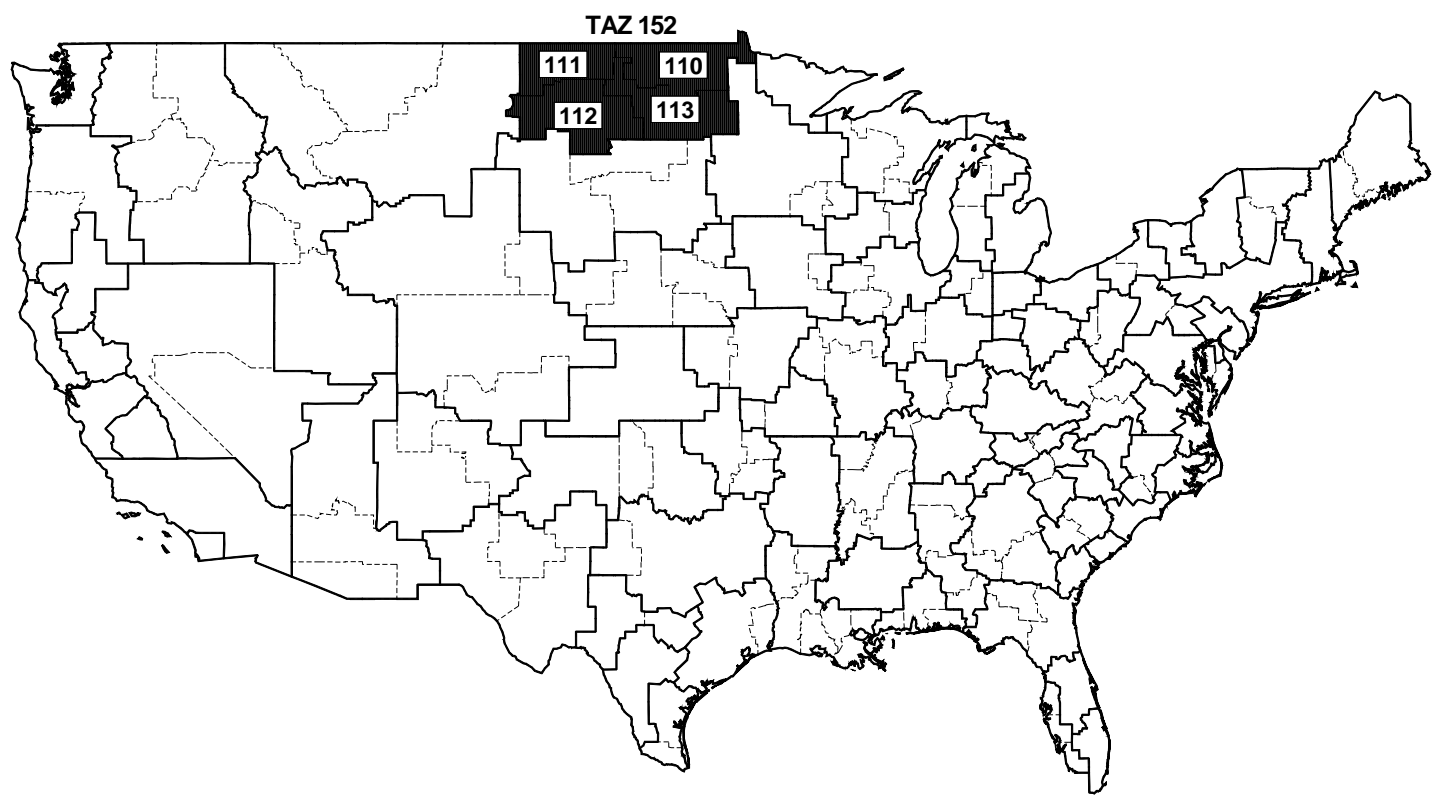

Figure 4. Transportation Analysis Zones.

The model estimates the OD table by determining route flows, denoted by $f_{r}$. This flow is the number of containers that travel on a route from a specific origin country to a specific TAZ. In this model, a route $r$ consists of an origin country $o$, foreign departure port $p^{\prime}$, U.S. port $p$, and destination TAZ $d$. Figure 6 below illustrates two sample routes from the country of Germany to the TAZ that includes Houston, TX. The first route goes through the Port of Lisbon in Portugal and then the Port of New York, whereas the second route goes through the port of Bremerhaven in Germany and then the Port of New York. Note there is a distinction between origin country $o$ and what we call departure country $o^{\prime}$, the country where the cargo is loaded onto a ship destined for the U.S. Therefore, each departure country $o^{\prime}$ has a collection of ports $p^{\prime}$ associated with it. As seen in Figure 5 below, the departure country $o^{\prime}$ may or may not be the same as the origin country $o$. There are thus four types of nodes in this model: nodes that represent the foreign countries (of which there are 67), nodes that represent the foreign ports (of which there are 455), nodes that represent the U.S. ports 


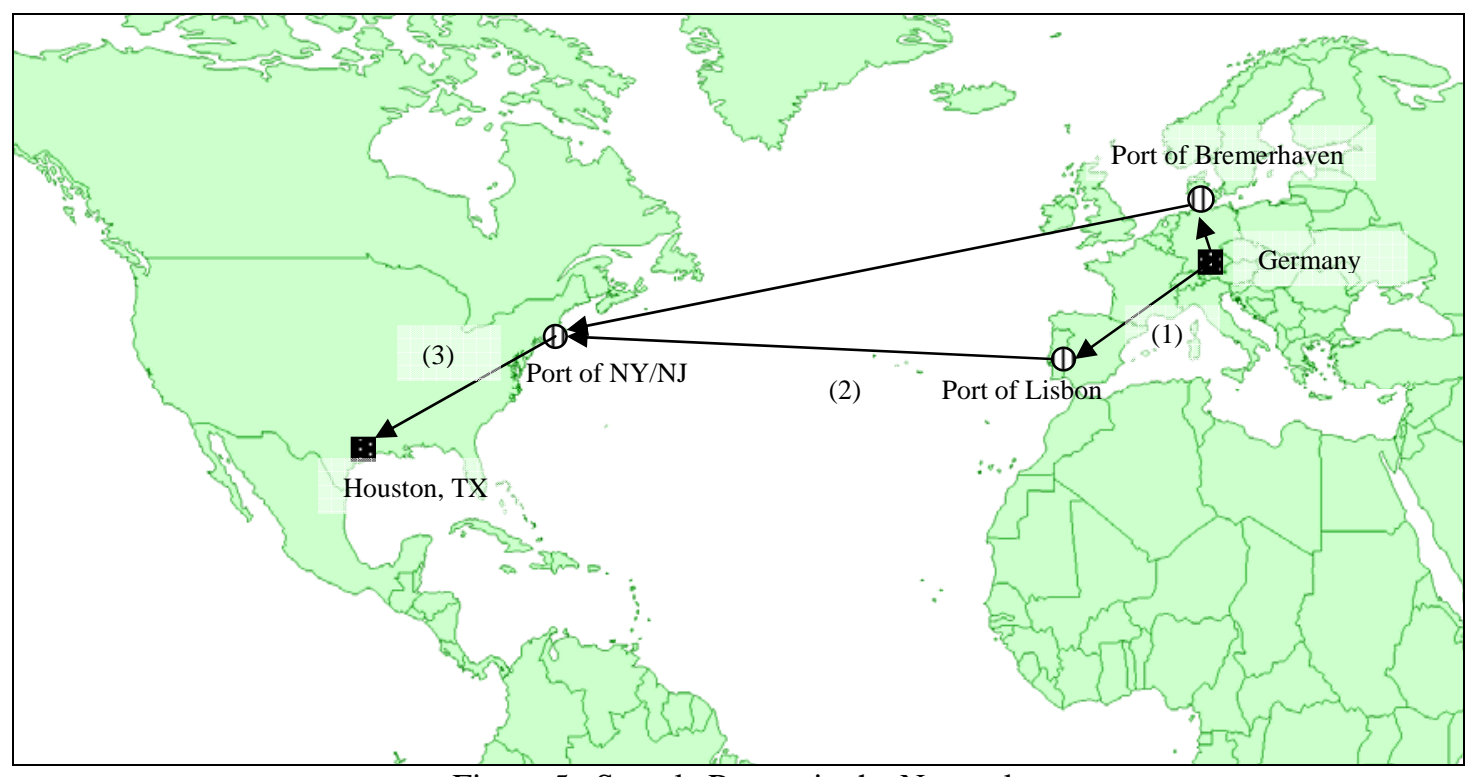

Figure 5. Sample Routes in the Network

(of which there are 32) and nodes that represent each traffic analysis zone (of which there are 84).

The network described above also consists of a set of links $(i, j)$ that connect nodes in the network. Thus, there are three types of links for which we have observations: (1) links starting at an origin country $o$ and ending at departure port $p^{\prime}$; (2) links starting at departure port $p^{\prime}$ and ending at U.S. port $p$; and (3) links starting at U.S. port $p$ and at a TAZ $d$. We also have observations for groups of links of type 3 for which all links in a particular group start at the same port p but end at different TAZs $d$.

Observations of flows on links of type (1), $t_{o p}$, and (2), $l_{p^{\prime} p}$, come directly from the 2004 PIERS dataset. Both types of link flows are hoped to be known with certainty, but deviations are allowed when either conflicts arise with the gravity model or are implied by differences with observations on other links. 
Observations of flows on links of type (3), $n_{p \tilde{d}}$, where $\tilde{d}$ is a group of TAZs, come from the 2003 Carload Waybill Sample. The STB Waybill is approximately a 3\% sample of rail traffic and therefore provides a detailed picture of rail movements over the rail network each year. Wolfe and Linde (1997) provide a useful description of the Waybill Sample and explain how it can be effectively used. However, the transportation of containers from a U.S. port $p$ to a TAZ $d$ can be either by truck or by rail, with rail substantially more likely as the distance from the port increases. Therefore, the Carload Waybill Sample provides a lower bound on the flow for these links. Again, we allow deviations in these flows where inconsistencies arise. It is also important to note that the STB Waybill does not explicitly identify the number of international containers transported. Rather, the STB Waybill identifies the number of carloads for STCC 46 transported from one county to another. This designation corresponds to mixed freight, which is used for intermodal shipments. Based on the origination county of these flows, we can attempt to infer which of these flows actually originated at a seaport.

In 2003, approximately 6 million TEU containers were imported through the Ports of Los Angeles and Long Beach. Leechman (2005) estimates, based on 2004 data, that rail traffic has about a $40 \%$ share from the Ports of Los Angeles and Long Beach. They also estimate that another 5\% of containers from these two ports are trans-loaded near the port into 53 foot containers for rail shipment. Therefore, we can infer that about 2.7 million TEU containers move by rail from the Ports of Los Angeles and Long Beach. Since the ports of Los Angeles and Long Beach are both in Los Angeles County, for the purposes of extracting flows of rail cars from the 2003 STB Waybill, these ports are considered together. According to the 2003 STB Waybill, 1,886,000 rail carloads of STCC 46 originated in Los Angeles County. Thus, if we assume that 
there are about 1.7 containers per railcar (Intermodal Association of North America, 2007), and that there are about 1.79 TEUs per container handled at these two ports (Pacific Maritime Association, 2007), we can infer that the total number of containers that originate in Los Angeles county is about 5.7 million TEU containers, of which about 2.7 million TEU containers originate at the ports.

Table 1 gives estimates of the number of containers (measured in TEUs and rounded to the nearest thousand) moved by rail from 12 of the largest ports. Miami is not included because the 2003 STB Waybill reports no rail carloads of STCC 46 originating in Miami-Dade County. It is not clear why this is the case, although the 2005 STB Waybill does have originations from Miami-Dade County. Leechman (2005) also provides estimates for the rail share from the Ports of Oakland, Seattle, and Tacoma. These have also been incorporated into the estimates of the number of containers moved by rail from each of these ports given below. For the remainder of the ports, we have no data to indicate what the share of rail might be. However, the number of TEU container originations implied by the rail carload originations in these counties is less than the number of containers handled at the ports, so it is reasonable to assume that all of the rail carloads originate at the ports themselves.

Table 1. Estimated Container Originations by Port

\begin{tabular}{|c|c|c|}
\hline Port & Counties & $\begin{array}{c}\text { TEU Containers } \\
\text { Moved by Rail }\end{array}$ \\
\hline LA/Long Beach & Los Angeles & $2,700,000$ \\
\hline Oakland & Alameda/Contra Costa/ San Joaquin & 365,000 \\
\hline Seattle/Tacoma & King/Peirce & 864,000 \\
\hline New York & Hudson, Union, Bergen, Essex & 843,000 \\
\hline Baltimore & Baltimore & 101,000 \\
\hline Norfolk & Norfolk, Portsmouth & 296,000 \\
\hline Charleston & Charleston & 160,000 \\
\hline Savannah & Savannah & 140,000 \\
\hline Port Everglades & Broward & 66,000 \\
\hline Houston & Harris & 450,000 \\
\hline
\end{tabular}


Using this information, we can estimate the spatial distribution of trips originating at each port. The fraction of the total number of TEU containers traveling by rail estimated to originate at that port can be applied to each observation in the STB Waybill that is assumed to originate in the associated county or counties. This gives an estimate of how many TEU containers travel between this port and each TAZ. Figure 6 gives these estimates for the Port of Los Angeles and Long Beach and the Port of New York. For example, this process implies that 370,000 containers (in TEUs) are bound for the Dallas area from the Ports of Los Angeles and Long Beach. It is useful to notice the large number of containers that are bound for Chicago, and to a lesser extent, Memphis. These are likely a result of the practice of "rebilling" on transcontinental rail movements, as discussed by Wolfe and Linde (2007). This occurs when carloads are interchanged between two railroads and therefore two separate waybills are generated, one for each segment of the movement. Since there is no mechanism to identify the follow-on movement, rebilling leads to over estimates of the traffic that terminates at interchange points such as Chicago and Memphis. To account for the practice of rebilling in the model, we assume that for ports on the east coast, observations of TEU containers into the TAZs that include Chicago and Memphis really reflect the flow of TEU containers bound for those TAZs as well as TAZs to the west. Similarly, for ports on the west coast, observations of TEU container flows for the TAZs that include Chicago and Memphis are assumed to be bound for those TAZs as well the TAZs to the east. These assumptions are reasonable given both the practice of rebilling and the fact that shippers tend to minimize their shipping distance; therefore, the follow-on movement is likely in the same general direction. 


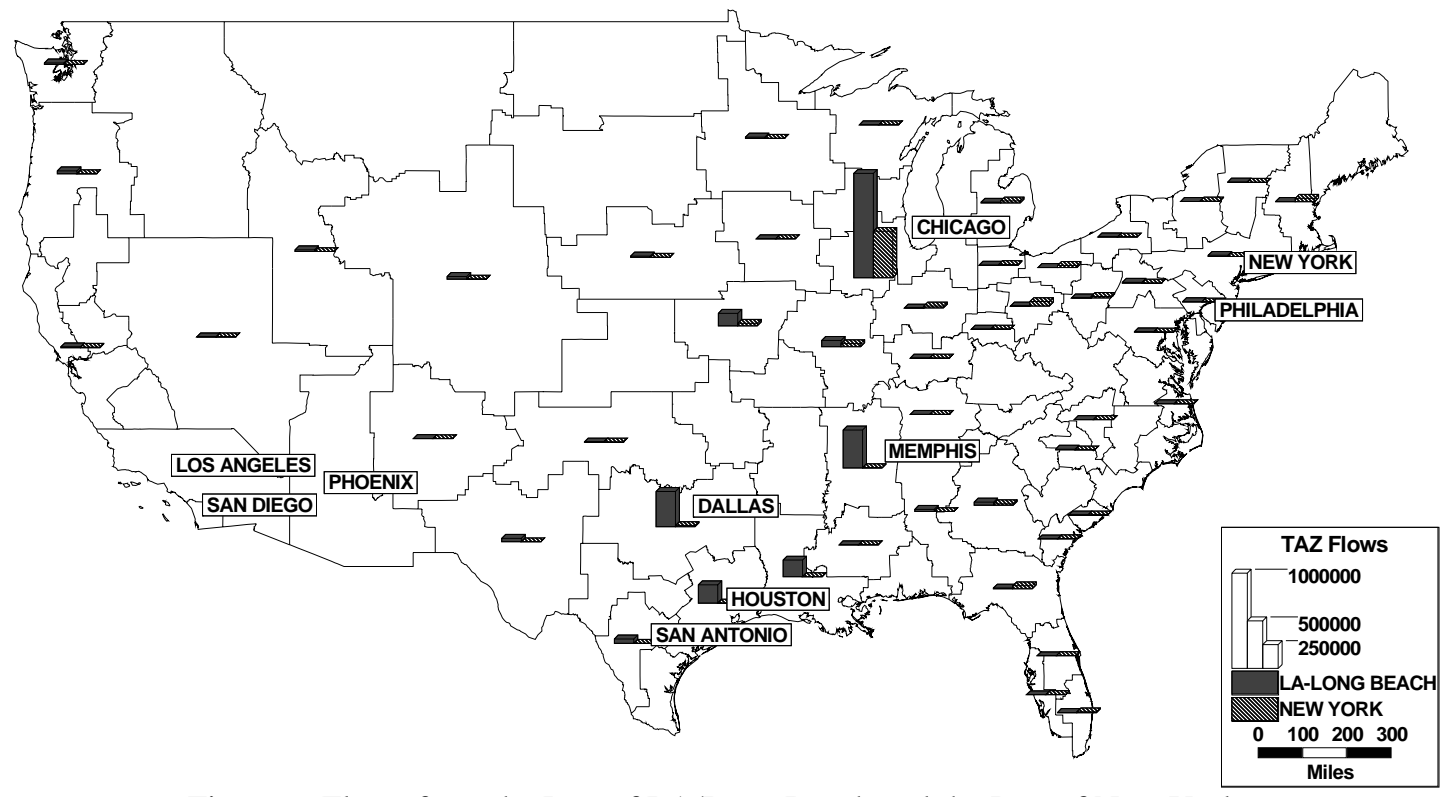

Figure 6. Flows from the Port of LA/Long Beach and the Port of New York to each TAZ based on the 2003 STB Waybill

Before describing the model in more detail, we present the following sets and parameters. Let $(i, j)$ be the set of all links where $i$ is the origin node of the link and $j$ is the destination node of the link. As mentioned, each node is a foreign country, a foreign port, a U.S. port, or a TAZ. Let $r$ be an index over the set of all routes. Let $p$ be an index over the set of all U.S. ports. Let $p^{\prime}$ be an index over the set of all foreign ports. Let $p^{\prime}(r)$ be the set of all routes that use foreign port $p^{\prime}$. Let $r_{i j}$ be the set of all routes that include link $(i, j)$. Let $p(r)$ be the set of all routes that include U.S. port $p$. Let $R_{o d}$ be the set of all routes connecting origin $o$ with destination $d$.

The key decision variables in this model are the number of containers on route $r, f_{r}$, where each route is a path from an origin country $o$, through a foreign port $p^{\prime}$, to a U.S. port $p$, to a TAZ $d$. These route flows can then be translated into an origin destination table by summing the route flows which have the same origin country and destination TAZ. These variables are constrained to be non-negative. 
The PIERS international trade dataset gives the number of containers (in TEUs) that travel along each link from origin $o$ to foreign port $p^{\prime}, t_{o p}$. The first term on the left hand side of equation (1) is the sum of the route flows that use both origin $o$ and foreign port $p^{\prime}$. The next two terms are variables that represent the amount by which the route flows are lower or greater than that implied by the PIERS data $t_{o p^{\prime}} \cdot u_{o p^{\prime}}^{+}$is constrained to be non-negative and $u_{o p}^{-}$is constrained to be non-positive. Therefore constraint (1) attempts to identify route flows that are as consistent as possible with the number of containers (in TEUs) shipped from each origin country to each foreign port of export.

$$
\sum_{r \in r_{i j} \mid i=o, j=p^{\prime}} f_{r}+u_{o p^{\prime}}^{+}+u_{o p^{\prime}}^{-}=t_{o p^{\prime}} \quad \forall o, p^{\prime}
$$

The PIERS dataset also gives the total number of containers (in TEUs) that are shipped from each foreign port $p^{\prime}$ to each U.S. port $p, l_{p^{\prime} p}$. The first term on the left hand side of equation (2) is the sum of the route flows that use both foreign port $p^{\prime}$ and domestic port $p$. The next two terms are variables that represent the amount by which the route flows are lower or greater than that implied by the PIERS data $l_{p^{\prime} p} \cdot g_{p p^{\prime}}^{+}$is constrained to be non-negative and $g_{p^{\prime} p}^{-}$is constrained to be non-positive. Therefore constraint (2) attempts to identify route flows that are as consistent as possible with the number of containers (in TEUs) shipped from each foreign port to each U.S. port.

$$
\sum_{r \in r_{i j} \mid i=p^{\prime}, j=p} f_{r}+g_{p p^{\prime}}^{+}+g_{p^{\prime} p}^{-}=l_{p^{\prime} p} \quad \forall p^{\prime}, p
$$

Given the link flow observations $l_{p^{\prime} p}$ from the PIERS data, it is possible to compute the total number of containers (in TEUs) that depart each foreign port $p^{\prime}, b_{p}$. Constraint (3) attempts to identify values for the route flows, $f_{r}$, that match the PIERS 
data for the number of containers that pass through each foreign port. However, deviations are allowed. $e_{p^{\prime}}^{+}$is a variable that represents the amount by which the flows, $f_{r}$, are smaller than that expected based on the PIERS data and $e_{p^{\prime}}^{-}$is a variable that represents the amount by which the flows, $f_{r}$, are larger than expected. $e_{p^{\prime}}^{+}$is constrained to be non-negative and $e_{p^{\prime}}^{-}$is constrained to be non-positive.

$$
\sum_{r \in p^{\prime}(r)} f_{r}+e_{p^{\prime}}^{+}+e_{p^{\prime}}^{-}=b_{p^{\prime}} \quad \forall p^{\prime}
$$

Additionally, given the same link flow observations $l_{p^{\prime} p}$ from the PIERS data, it is also possible to compute the total number of containers (in TEUs) that enter each U.S. port, $m_{p}$, and then penalize deviations from these values. Constraint (4) encourages solutions that match the container volumes entering each U.S. port, but deviations are allowed. $h_{p}^{+}$is a variable represents the amount by which the flows, $f_{r}$, are smaller than that expected based on the PIERS data and $h_{p}^{-}$is a variable that represents the amount by which the flows, $f_{r}$, are larger than expected. $h_{p}^{+}$is constrained to be nonnegative and $h_{p}^{-}$is constrained to be non-positive.

$$
\sum_{r \in p(r)} f_{r}+h_{p}^{+}+h_{p}^{-}=m_{p} \quad \forall p
$$

Constraint (5) incorporates observations of container flows from the 2003 STB Waybill data. Each observation in the waybill applies to a group of links $(i, j)$ starting from a U.S. port and ending at a TAZ or group of TAZs. The total freight shipped across those links must be at least as large as that implied by the 2003 STB Waybill data, $n_{p \tilde{d}}$, where $p$ is the port and $\tilde{d}$ is the set of TAZ destinations that the observation pertains to. The set $\tilde{d}$ may be composed of a single destination TAZ or a collection of destination TAZs. The observations in the STB Waybill are lower limits 
on the link flows for two reasons. First, the observations only include rail movements from the ports, and therefore exclude those shipped by truck. Second, we are using the 2003 STB Waybill rather than the 2004 dataset, and since containerized traffic has been growing at about 8\% per year, we can expect that the 2004 values for the flows from the Waybill are generally greater than those in the 2003 (Intermodal Association of North America, 2007). The first term on the left hand side of Equation (5) is the sum of the route flows that use U.S. port $p$ and terminate at a TAZ in the set $\tilde{d}$. The right hand side is the total number of TEU containers indicated by the 2003 STB Waybill that enter a port $p$ and terminate at one of the TAZs in the set $\tilde{d} \cdot k_{p d}^{+}$is a variable that represents the amount by which the flows, $f_{r}$, are smaller than suggested by the STB Waybill. $k_{p d}^{+}$is constrained to be non-negative.

$$
\sum_{r \in r_{i j} \mid i=p, j \in \tilde{d}} f_{r}+k_{p \tilde{d}}^{+} \geq n_{p \tilde{d}} \quad \forall p, \tilde{d}
$$

For all TAZs, except the ones that include Chicago and Memphis, the observations in the STB Waybill pertain to a single destination TAZ. We do not write a lower limit for the TAZ that includes Chicago or the TAZ that includes Memphis separately from each port. Rather, if the port is on the west coast, we write a lower limit constraint that pertains to all TAZs to the east of the Mississippi River. If the port is on the east coast, we write a lower limit that pertains to all TAZs west of the Mississippi River plus the TAZs that include Chicago and Memphis. We compute this lower limit by summing the flows given in the Waybill from that particular port to each of the TAZs that the constraint pertains to. This allows the model to re-distribute the containers that the Waybill associates with Memphis and Chicago to other TAZs in the appropriate group from each port. 
We can also create upper bounds on the flows from the ports to some of the TAZs from the 2003 STB Waybill. It is reasonable to assume that containers entering the U.S. through west coast ports would primarily move by rail if the destination TAZ is in the east. Similarly, it is reasonable to assume that containers entering the U.S. through east coast ports move primarily by rail if the destination is a TAZ is in the west. We use the Mississippi River as the geographic boundary of the East with the caveat that the TAZs that include Chicago and Memphis are assumed to be on the "rail only” side. For West Coast ports, this is consistent with the geographic boundary of the Mississippi. For East Coast ports, this assumes that the TAZs that include Chicago and Memphis are grouped with the TAZs to the West of the Mississippi River.

Let $\delta_{p}$ be the set of all TAZs $d$ that are considered to be serviced only by rail from U.S. port $p$. Let $x_{p}$ be the number of TEU containers that originate at port $p$ and terminate at TAZs that are exclusively served by rail as given in the 2003 STB Waybill. $y_{p}^{-}$is a variable that indicates the amount by which the flows are larger than that suggested by the upper limits derived from the STB Waybill. $y_{p}^{-}$is constrained to be non-positive.

$$
\sum_{r \in r_{i j} \mid i=p, j \in \delta_{p}} f_{r}+y_{p}^{-} \leq \gamma_{p} x_{p} \quad \forall p
$$

where $\gamma_{p}$ is an inflation factor. The inflation factor can be used to represent the amount above the values in the STB Waybill for which deviations are considered acceptable. It can also be used to compensate for the growth that has occurred between the time period of the PIERS international trade data and the STB Waybill. We use the growth that occurred between 2003 and 2004 at each of the ports as estimated by the U.S. Maritime Administration (U.S. Maritime Administration, 2007). 
Thus, constraint (6) states that for each U.S. port $p$, the sum of the route flows to all destinations serviced only by rail must be at most the observation value in the STB waybill, increased by some inflation factor.

In order to give the model additional guidance as to how to determine the route flows and therefore the origin-destination table, we can incorporate a gravity model into the mathematical formulation. Constraint (7) is a gravity model for the movement of seaborne containerized freight imports from origin country o to TAZ $d$.

$$
B_{o d}=K_{o} G_{o} G_{d} d_{o d}^{-\lambda} \quad \forall o, d
$$

where $B_{o d}$ is the number of containers (in TEUs) shipped from origin country $o$ to TAZ $d, G_{\mathrm{o}}$ is the GDP of origin country $o$ (World Bank, 2007), $G_{d}$ is the earnings in TAZ $d$ (U.S. Commerce, 2007), $d_{o d}$ is the distance $o$ to $d$ and $K_{o}$ is a country specific variable (what is commonly referred to as a $K$-factor in the freight demand modeling literature). Equation (7) can be simplified because $K_{o}$ and $G_{o}$ can be grouped together, since they are constant for a particular origin. If we then assume that $d_{o d}$ is the shortest route from $o$ to $d$ measured in travel time, and that $\lambda$ is a constant, then $d_{o d}^{-\lambda}$ is a constant for each origin-destination pair. The simplification is then given as equation (8) below, where $\hat{K}_{o}$ and $B_{o d}$ are the two decision variables, both of which are constrained to be non-negative.

$$
B_{o d}=\hat{K}_{o} G_{d} d_{o d}^{-\lambda} \quad \forall o, d
$$

This equation implies that the number of containers that flow from origin country $o$ to destination TAZ $d$ is proportional to both the GDP of the destination TAZ $d$ and the 
distance from country $o$ to TAZ $d$. These are reasonable assumptions for two reasons. First, much of what is transported in waterborne containers are retail goods and the consumption of these goods is reasonably assumed to be proportional to economic activity. Second, distance has a negative impact on the demand for transportation. It is also important to realize that the PIERS international trade data provides substantial information on the total number of TEUs imported from each country. Hence, there is substantial information on the sum of the $B_{o d}$ variables for a given $o$. This information is integrated into the model through equation (1).

Ashtakala and Murthy (1988 and 1993) use a similar gravity model for land-based freight transportation and find that value of $\lambda$ varies from 0.25 to 1.0 depending on the commodity. Ashtakala and Murthy (1988) also observe that higher exponent values are associated with the transportation of lower value goods. They reference two other studies that draw the same conclusion (Chisholm and O’Sullivan (1973) and Black (1971)). Since this model focuses on international waterborne shipments and the associated domestic land movement, it is unclear what an effective value of the exponent will be. One strategy to address this is to use different values for the exponent and select the one that appears to fit the data best; that is, generates the least amount of discrepancies with the data in the PIERS international trade dataset, the STB Waybill, and the resultant gravity model.

Constraint (9) allows the model to select route flows that deviate from the gravity model given in equation (8). This is done by attempting to match the route flows from a given country $o$ to a TAZ $d$ to the gravity model estimate for the sum of those route flows, $B_{o d}$. Again, we include error terms to allow for deviations. $q_{o d}^{+}$is a variable represents the amount by which the flows, $f_{r}$, are smaller than that expected based on 
the gravity model and $q_{\text {od }}^{-}$is a variable that represents the amount by which the flows, $f_{r}$, are larger than expected. $q_{o d}^{+}$is constrained to be non-negative and $q_{o d}^{-}$is constrained to be non-positive.

$$
\sum_{r \in R_{o d}} f_{r}+q_{o d}^{+}+q_{o d}^{-}=B_{o d} \quad \forall o, d
$$

The goal of this formulation is to identify route flows for containerized international freight traffic that enters the U.S. through seaports which is as consistent as possible with: (1) observations of flows from each foreign origin country to each foreign port of export; (2) observations of flows from each foreign port to each US port; (3) the total freight leaving each foreign seaport that is destined for the U.S.; (4) the total freight entering each US port; (5) the number of containers shipped by rail from the largest U.S. seaports to each TAZ or group of TAZs; (6) for each port, the number of TEU containers destined for the TAZs that are served by rail only; (7) a gravity model between origin country $o$ and TAZ $d$ based on GDP for each foreign country, earnings for each TAZ and the distance between them. (1)-(4) is obtained from the 2004 PIERS international trade dataset and (5)-(6) is obtained from the 2003 STB Waybill.

The objective is given in equation (10) below. The first term in the objective penalizes deviations from estimates of the number of containers that are exported from each foreign country through each foreign port. The second term penalizes deviations from the flows of containers from each foreign port to each U.S. port. The third term in the objective penalizes deviations from estimates of the number of containers that are exported from each foreign port to the U.S. The fourth term penalizes deviations from estimates of the number of containers that are imported through each U.S. port. The fifth term penalizes flows that are lower than that implied by the 2003 STB 
Waybill from each U.S. port to each TAZ or group of TAZs. The sixth term penalizes flows that are higher than that implied by the 2003 STB Waybill for the largest U.S. ports to each group of TAZs that are served by rail only. The seventh term penalizes deviations from the gravity model. The final term in the objective minimizes the total distance represented by all of the route flows where $D_{r}$ is the distance of the $r^{\text {th }}$ route. We include this term to encourage the use of shorter routes, when possible, because this will produce a more reasonable solution. We use the rail distance to compute the land portion of the route distance, because if substantial travel is required on land, it is more likely to be done by rail than by truck.

$$
\begin{gathered}
\sum_{\left(p^{\prime}, p\right)} \alpha_{0}\left(u_{o p^{\prime}}^{+}-u_{o p^{\prime}}^{-}\right)+\sum_{\left(p^{\prime}, p\right)} \alpha_{1}\left(g_{p^{\prime} p}^{+}-g_{p^{\prime} p}^{-}\right)+\sum_{p^{\prime}} \alpha_{2}\left(e_{p^{\prime}}^{+}-e_{p^{\prime}}^{-}\right)+ \\
\sum_{p} \alpha_{3}\left(h_{p}^{+}-h_{p}^{-}\right)+\alpha_{4} \sum_{p d} k_{p d}^{+} \tilde{d}-\alpha_{5} \sum_{p} y_{p}^{-}+\sum_{(o, d)} \alpha_{6}\left(q_{o d}^{+}-q_{o d}^{-}\right)+\beta \sum_{r} f_{r} D_{r}
\end{gathered}
$$

$\alpha_{o}, \alpha_{1}, \alpha_{2}, \alpha_{3}, \alpha_{4}, \alpha_{5}$ and $\alpha_{6}$ are coefficients that reflect the relative importance of deviations from each set of constraints, and $\beta$ is a per container mile penalty for travel distance. We penalize separately (1) deviations from expected total port container volumes at foreign ports and U.S. ports; (2) deviations from the observations of flows from individual foreign countries to individual foreign ports; and (3) deviations from the observations of flows from individual foreign ports to individual U.S. ports, because generally it is more important to match the total volumes at each port than it is to match the flows of containers between specific ports. It is also likely that the observations of total volumes at ports are more reliable than those on individual foreign port to U.S. port movements. By setting the coefficients $\alpha_{3}$ and $\alpha_{4}$ higher than $\alpha_{0}$ and $\alpha_{1}$, this can be achieved. Since the data that supports the first four terms is derived from the PIERS international trade data, and that data is internally consistent, the trade-off in the objective is really between the first four terms, the fifth and sixth 
which come from the 2003 STB Waybill, and the distance term. The distance term has the lowest penalty because it is simply used to choose between alternative optimal solutions. 


\section{CHAPTER 3}

\section{INSIGHTS FROM THE MODEL}

This section focuses on the model results and insights that can be gained from the route flows and estimated origin-destination table. This origin-destination table is included in the appendix. When the exponent on the distance term in the gravity model (equation 8) is 1.2, the origin-destination table is consistent with both the 2004 PIERS international trade data for containerized imports and the gravity model. However, there is one inconsistency with the observations in the 2003 STB Waybill that were used to generate lower bound constraints (equation 5), and one inconsistency with the observations in the 2003 STB Waybill that were used to generate upper bound constraints (equation 6). These discrepancies are given in Table 2. The only discrepancy of significant magnitude is that from the Port of Houston to Los Angeles. The estimated route flows from the model imply that about 190,000 TEU containers enter at the Port of Houston and are bound for the Los Angeles area. The 2003 STB Waybill implies there are about 347,000 TEU containers that are shipped from the Port of Houston to the Los Angeles area by rail. Hence, there is a discrepancy of about 157,000 TEU containers. The 347,000 TEU containers reported in the Waybill represents about $77 \%$ of all rail movements from the Port of Houston estimated from the 2003 STB Waybill. While there is no evidence to discount this observation in the Waybill, the magnitude of the observation is somewhat inconsistent with the

Table 2. Discrepancies with the 2003 STB Waybill

\begin{tabular}{|c|c|c|}
\hline & Constraint & Error \\
\hline Houston - Los Angeles TAZ & Lower Bound, Eqn (5) & 157,000 \\
\hline $\begin{array}{c}\text { Ports of LA \& Long Beach } \\
\text { to TAZs East of Mississippi }\end{array}$ & Upper Bound, Eqn (6) & $-62,000$ \\
\hline
\end{tabular}


remainder of the traffic at the Port of Houston (which is more local in nature). The other discrepancy arises from a violation of the upper bound constraint. The 2003 STB Waybill and the growth rate at the ports of Los Angeles and Long Beach from 2003 to 2004 implies that about 1.8 million TEU containers travel from the ports of Los Angeles and Long Beach to all TAZ east of the Mississippi River, whereas the model estimates that this number is low by about 62,000 TEU containers. However, this represents an error of only about $3.5 \%$.

From the route flows and the estimated origin-destination table, the flow of TEU containers can be tracked through the network. If we consider the traffic originating abroad in China, about 95\% of TEU containers exported from Mainland China are shipped through eight Mainland Chinese ports, the Port of Hong Kong, the Port in Busan, South Korea and through the Port of Kaohsiung, Taiwan. These ports and the TEU containers imported are illustrated in Figure 7. It is useful to notice the concentration of activity at the Shanghai and Hong Kong port areas. The region from Shanghai to Hong Kong is a special economic zone with substantial financial incentives spurring tremendous growth. Historically, Hong Kong has been the dominant port, second only to Singapore. However, with the rapid growth in this special economic zone in China, the ports of Yantian and Shanghai have attracted substantial traffic. Today Shanghai is the second largest port in the world next to Singapore (Asian Economic News, 2007), with Hong Kong third.

Once TEU containers, originating in China, are exported through the collection of Asian ports mentioned above, the TEUs arrive at U.S. ports. Figure 8 gives the number of TEU containers imported from China through the six U.S. Ports with the highest volume. Together, these six ports represent about $94 \%$ of the total number of 


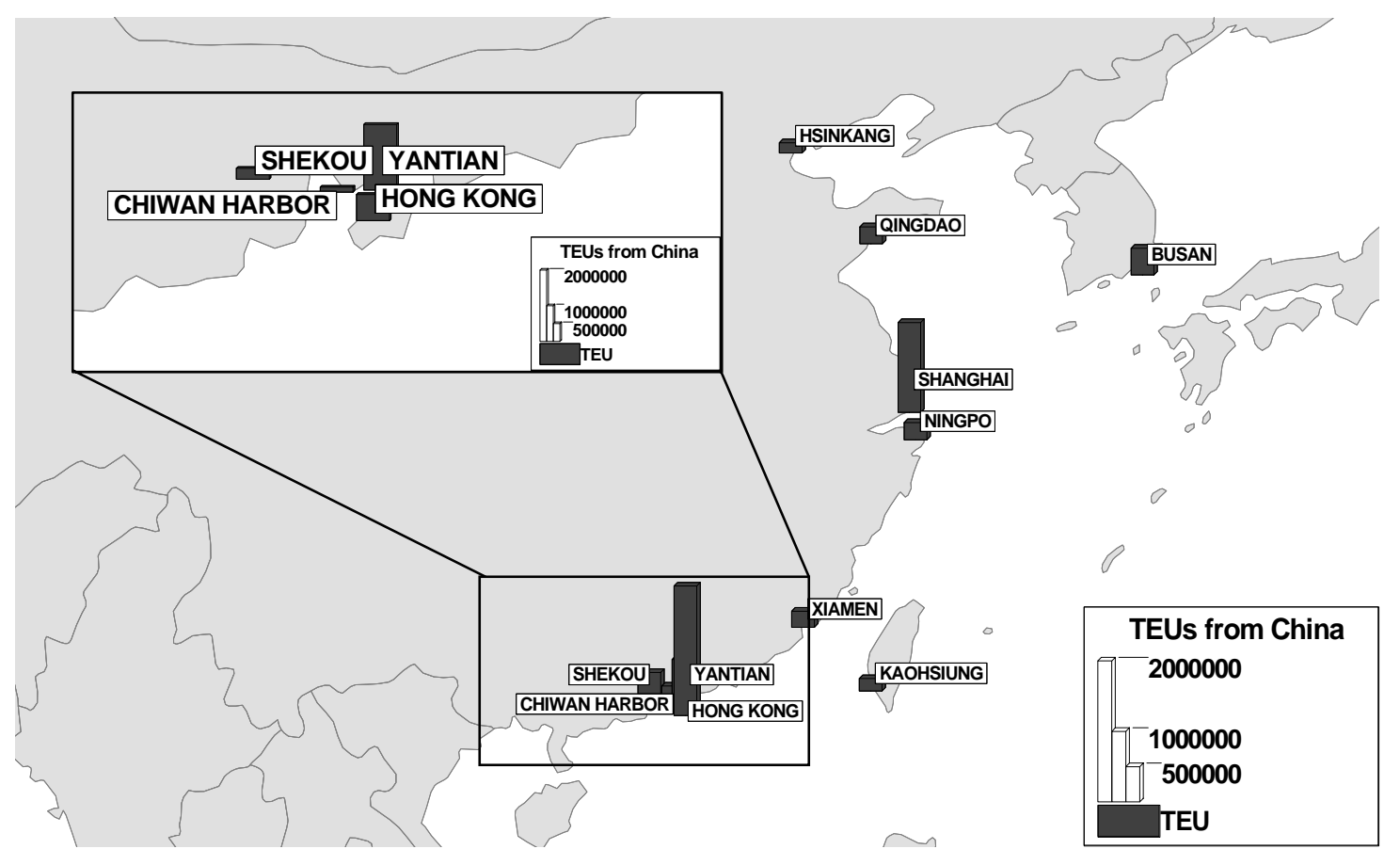

Figure 7. Export Port Volumes (in TEU Containers) from China

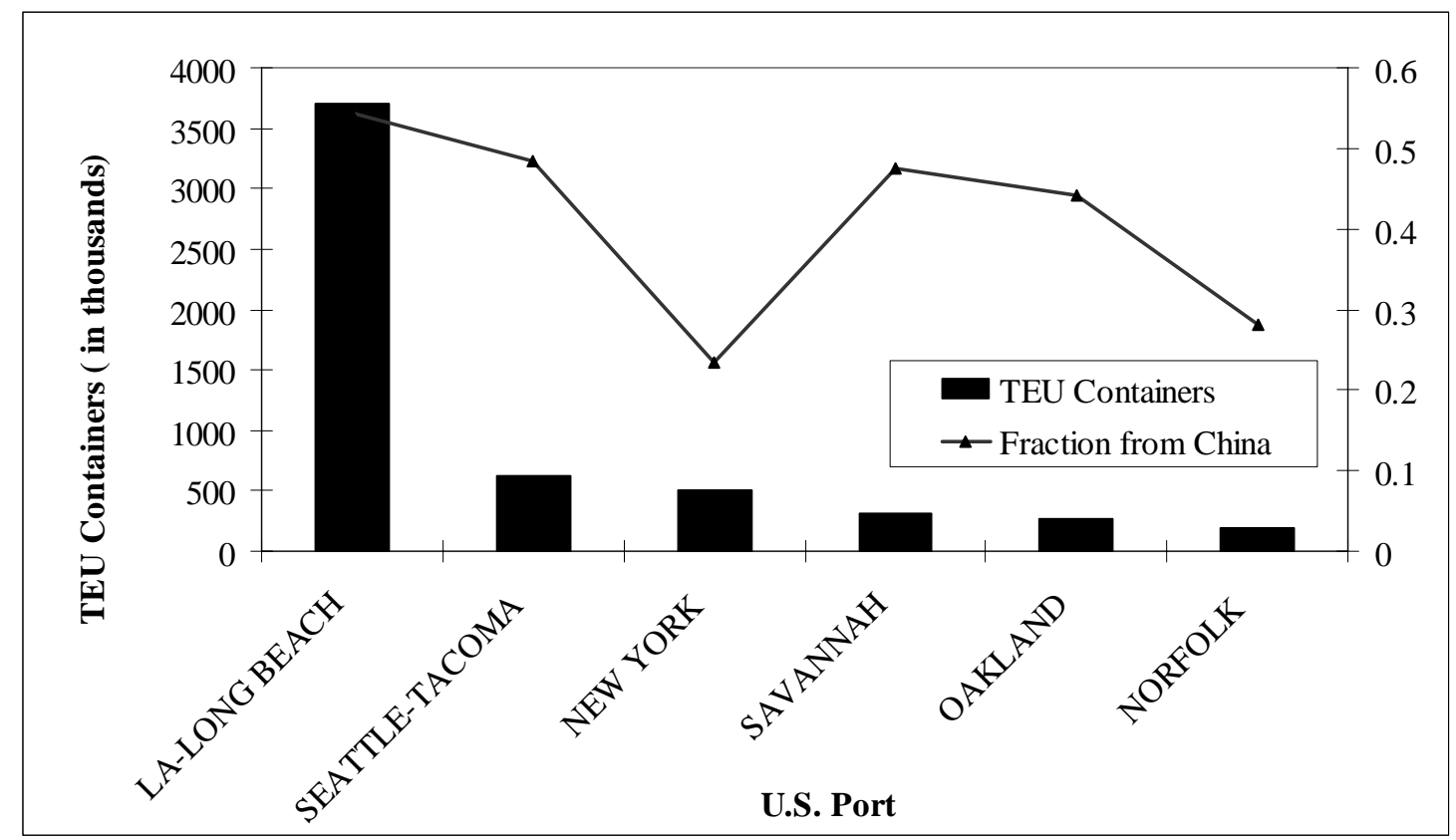

Figure 8. Port Volumes (in TEU Containers) from China 
containers imported from China. As expected, the majority of the TEU containers are imported through West Coast ports, but it is interesting to note that about $17 \%$ of the total number of TEU containers imported does so through the Ports of New York, Savannah, and Norfolk. Figure 8 also shows the fraction of TEU containers through each of the ports that originates in China. It is not surprising that the West Coast ports have a high percentage of traffic coming from China, but perhaps it is more surprising that East Coast ports, such as Savannah and Norfolk, have almost 50\% and 30\% of their traffic originating in China, respectively.

Figure 9 gives an estimate of the number of TEU containers imported from China that are destined for each TAZ. Notice that the large economic areas in the U.S. attract a large number of TEUs. For example, there are almost 600,000 TEUs destined for the New York City TAZ from China. The model estimates that about 75\% enters the U.S. through the Port of New York and about 25\% through the Ports of Los Angeles and Long Beach. On the other hand, shipments from China headed to the TAZs near Savannah and Norfolk enter almost exclusively through these ports and are served via truck. However, these conclusions should be used with some caution. This formulation has significantly more decision variables than equations, and linear programs tend to produce solutions that have relatively small numbers of variables that take on positive values, thereby producing "lumpy solutions". Therefore, individual TAZs may be served by a larger number of ports than indicated in the solution, though there is a strong basis to believe that the ports indicated in the solution do provide significant service. 


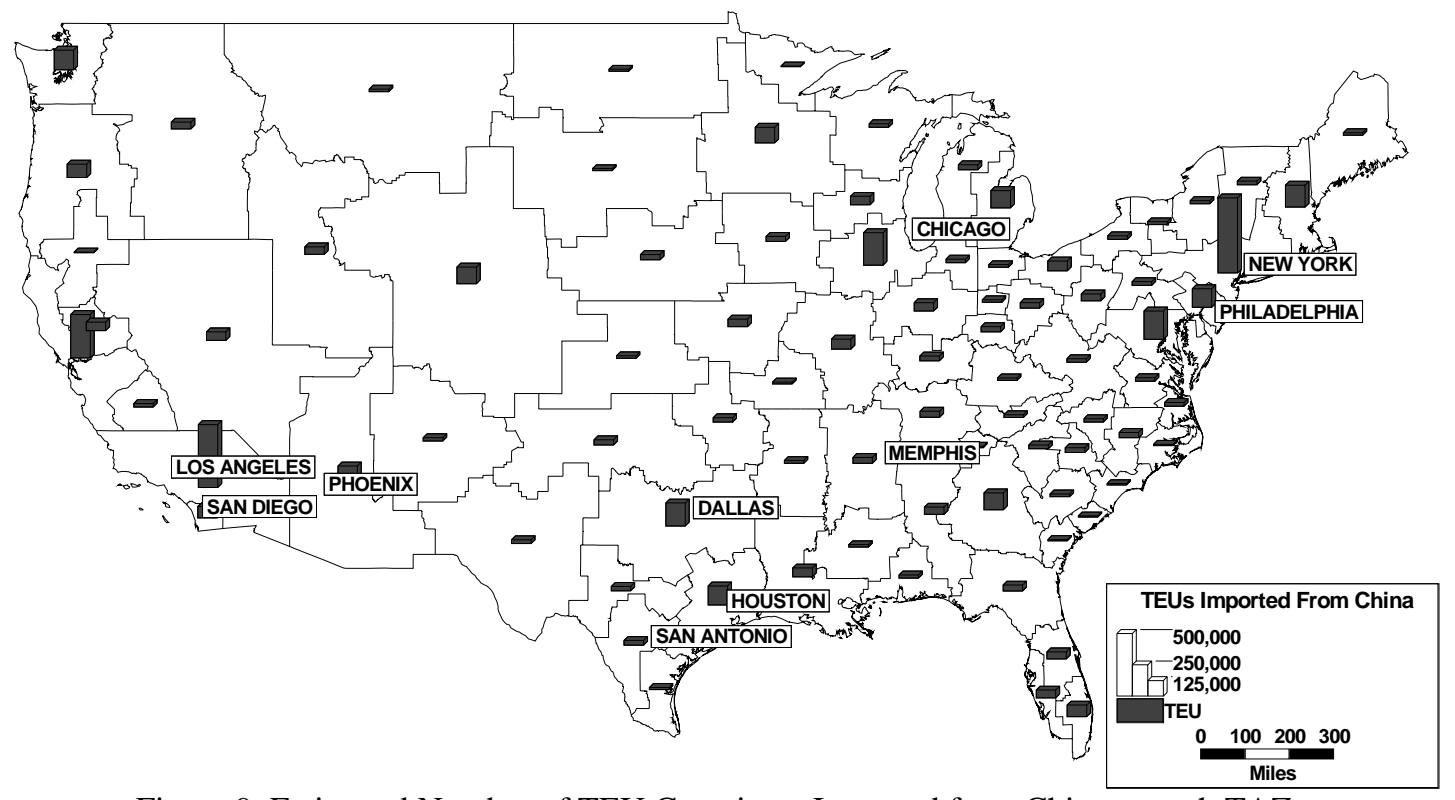

Figure 9. Estimated Number of TEU Containers Imported from China to each TAZ

Figure 10 gives the estimated number of TEU containers (by truck and rail) destined for each TAZ from the Ports of Los Angeles and Long Beach, the Port of Oakland, and the Ports of Seattle and Tacoma. Given that all but one upper bound constraint was honored in the model, we can also infer that all of the container volumes destined for TAZs east of the Mississippi River were achieved with rail service. It is interesting to notice that the Ports of Los Angeles and Long Beach are estimated to provide significant service across the U.S., with the exception of the southeast, whereas the Ports of Seattle and Tacoma provide service mainly in the north.

Figure 11 gives the estimated number of TEU containers (by truck and rail) destined for each TAZ from the Ports of New York, Charleston, Norfolk and Savannah. It is interesting to notice that the vast majority of the containers that enter the U.S. through these ports are destined for TAZs on the east coast. Very few containers travel west of the Mississippi River. This is in contrast to the ports on the West Coast, which service a large portion of the continental U.S. 


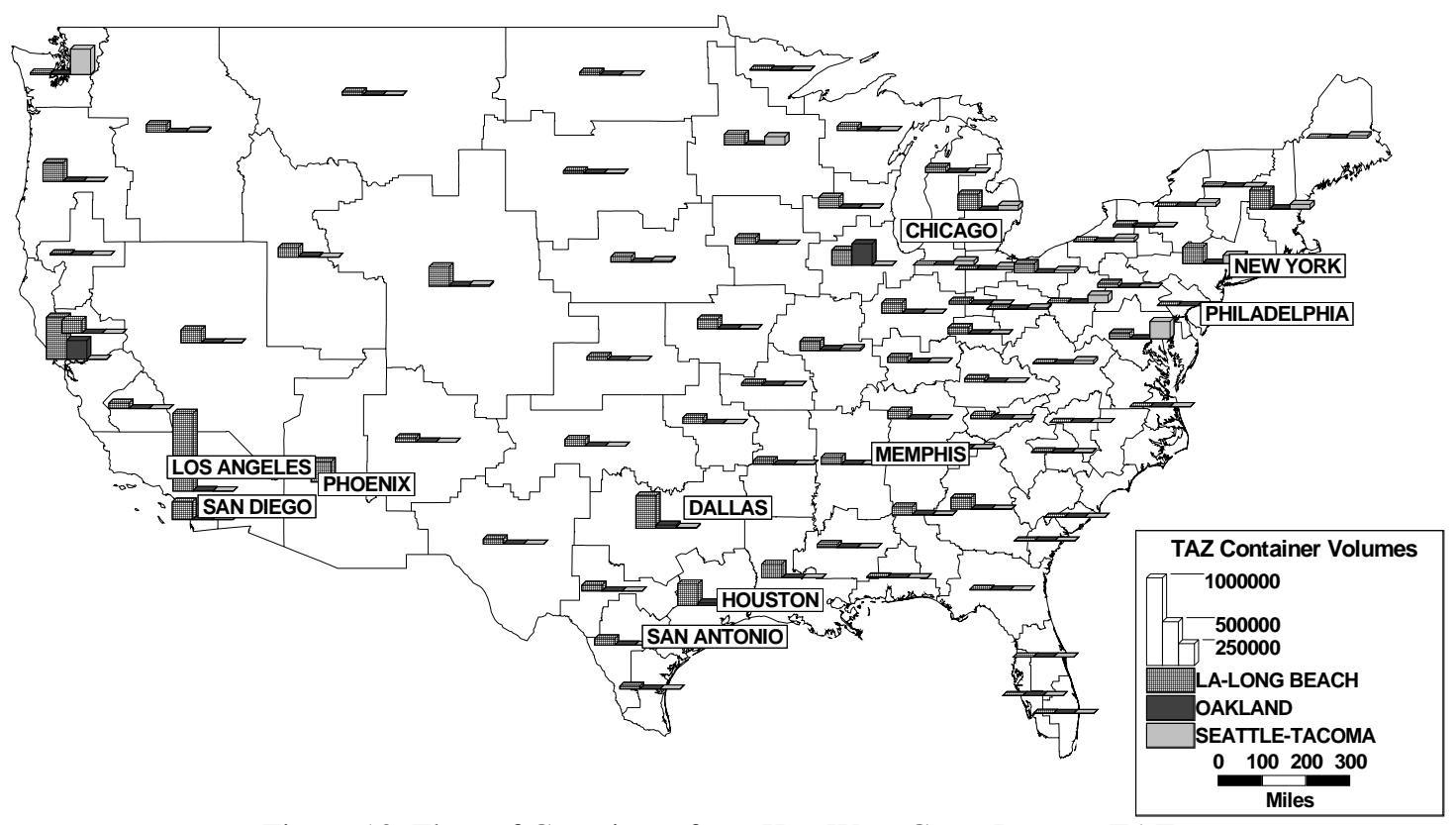

Figure 10. Flow of Containers from Key West Coast Ports to TAZs

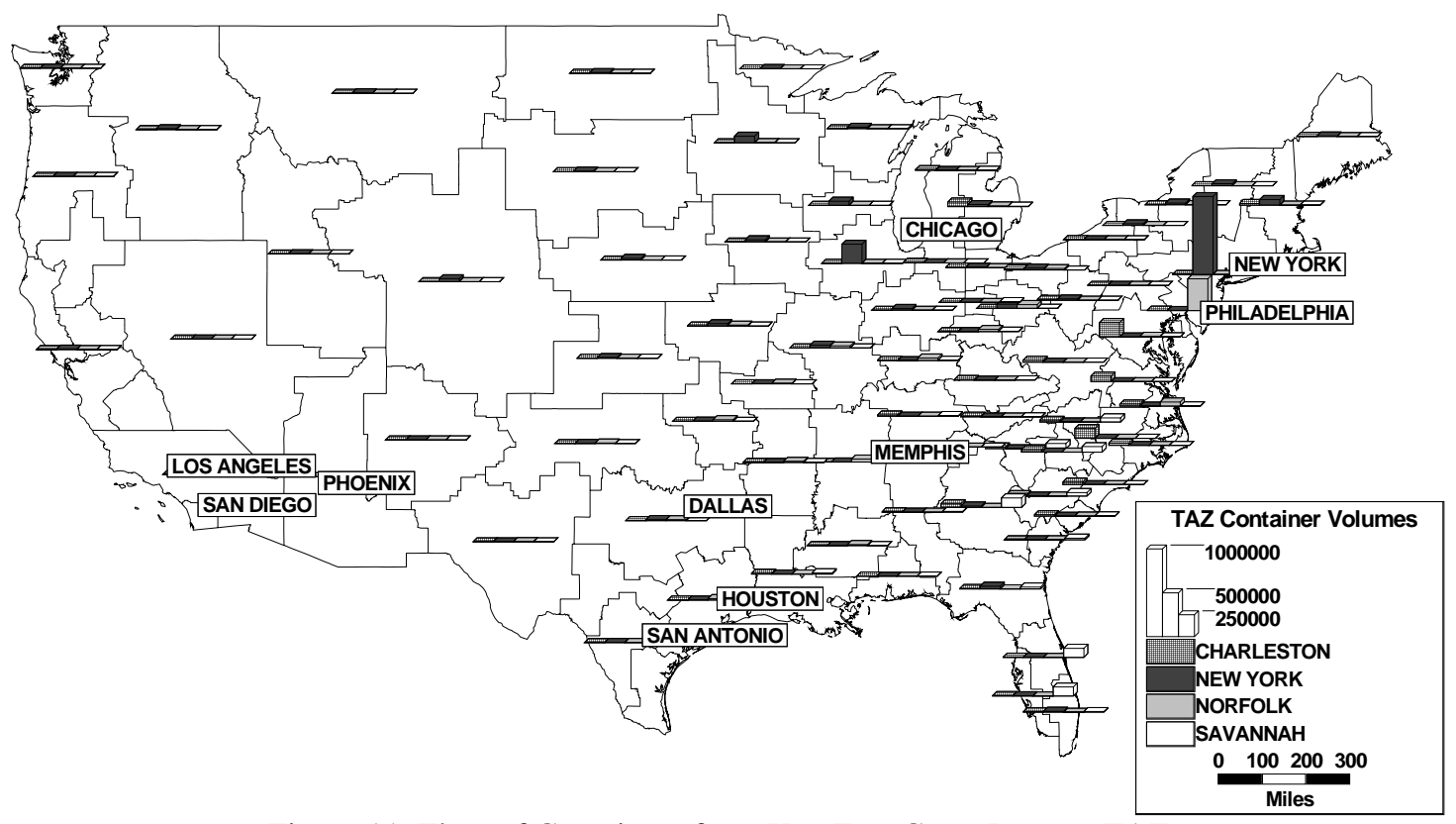

Figure 11. Flow of Containers from Key East Coast Ports to TAZs 
As mentioned previously, the STB Waybill indicates that more containers are destined for Chicago and Memphis then is likely to be correct, due to the practice of rebilling. We can use the model to infer the actual destinations for the containers that are labeled as destined for Chicago or Memphis in the STB Waybill. When doing this, it is important to understand that these flows are generally higher than those indicated by the 2003 STB Waybill because they include the growth that has occurred at these ports from 2003 to 2004 through Equation (6).

Figure 12 shows the estimated TEU container flows from both the Ports of Seattle and Tacoma and the Ports of Los Angeles and Long Beach to TAZs east of the Mississippi River, and that were indicated as terminating at Chicago or Memphis in the STB Waybill. The model concludes that some of this traffic does indeed terminate at the TAZs that include Chicago and Memphis, but much of it is destined for other TAZs. For example, the 2003 STB Waybill indicates that from the Ports of Seattle and Tacoma, about 600,000 TEU containers are destined for the TAZ that includes Chicago and about 35,000 are destined for the TAZ that includes Memphis. The model indicates that much of this traffic is really destined for the Northeast U.S. with significant concentrations in New York City, Boston, and to a lesser extent, Michigan and Ohio. On the other hand, the 2003 STB Waybill indicates that from the Ports of Los Angeles and Long Beach about 1,090,000 TEUs are destined for the TAZ that includes Chicago and about 400,000 TEUs are destined for the TAZ that includes Memphis. The model indicates that, just like the Seattle ports, much of this traffic is really destined for other TAZs east of the Mississippi River. Given the larger role of Memphis, substantial traffic is estimated to be destined for TAZs in the South. 


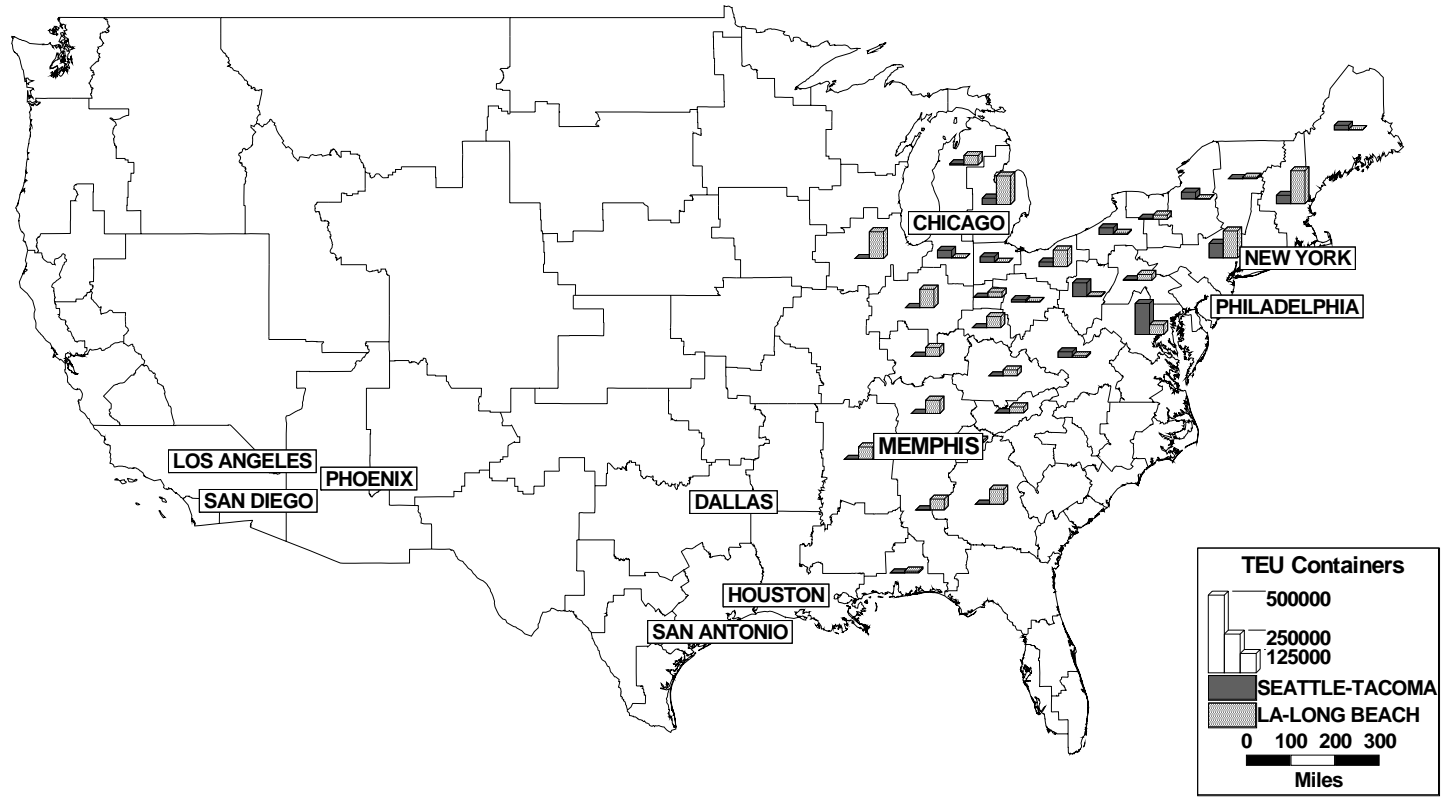

Figure 12. Inferred Flows from the Ports of Seattle and Tacoma and the Ports of Los Angeles and Long Beach that STB Waybill Reports as Terminating in Memphis or Chicago.

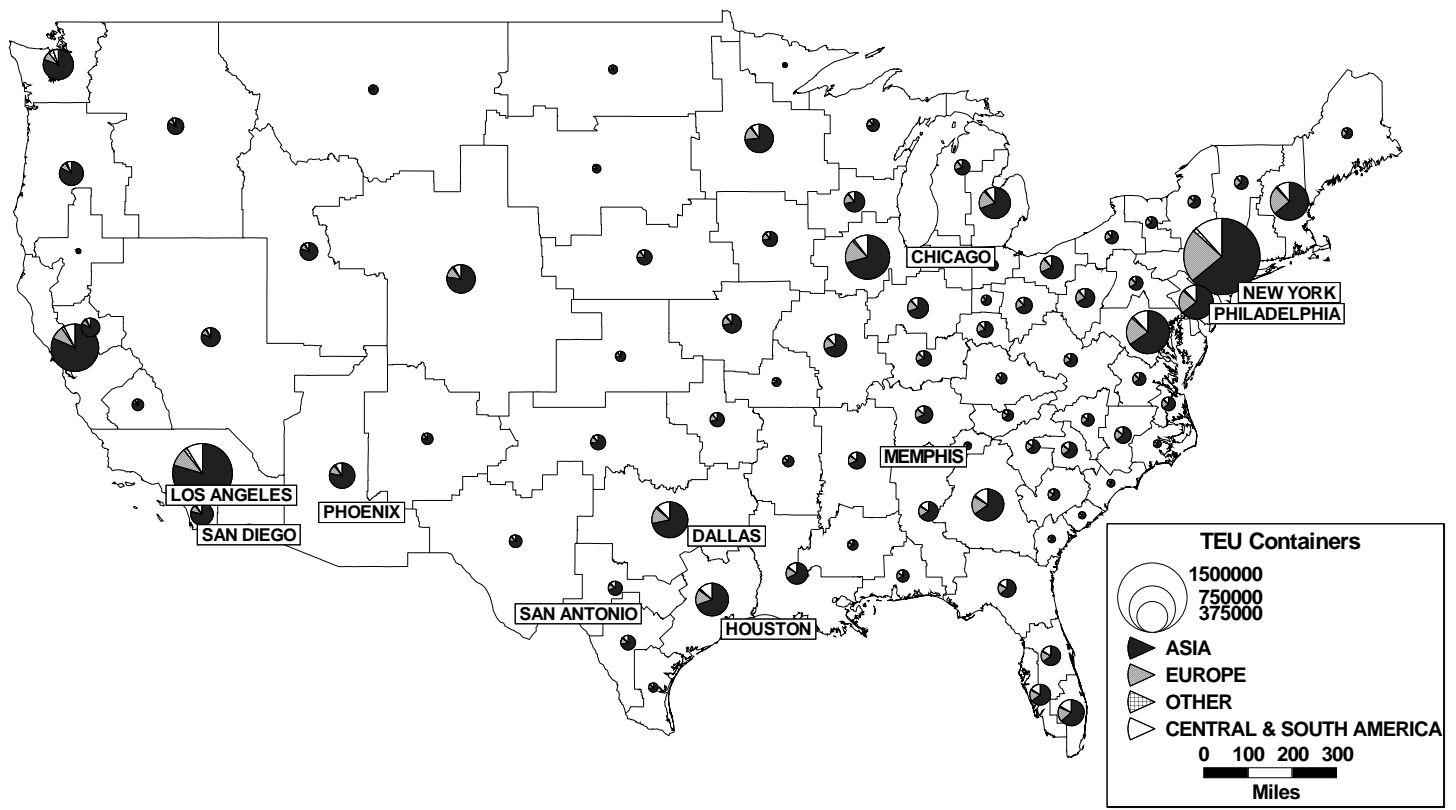

Figure 13. Distribution of TEU Containers Across Regions of Origin for Each TAZ 
Figure 13 gives the number of containers that are destined for each TAZ by originating region of the world (Asia, Europe, Central \& South America, other). Clearly, Asia is the dominant region. Perhaps the most interesting observations in this figure is how constant the balance is between the four regions of the world across the continental U.S. Certainly, there is a slight increase in the percentage from Asia in the west, Europe in the east, and Central \& South America in the south and gulf coast, but these shifts are still quite minor. For example, the TAZs with the largest percentage share from Asia are in California, Seattle, Oregon, Montana, Utah and Idaho (percentages in the low eighties). Whereas the TAZs with the smallest percentage share from Asia (percentages in the low sixties and among the highest from Europe) are in Maine, Florida, Georgia, South Carolina, Massachusetts, Pennsylvania, etc. Imports from Central \& South America are relatively larger in Florida, Georgia, South Carolina, and the Gulf Coast Region (percentages in the mid-teens). 


\section{CHAPTER 4}

\section{CONCLUSIONS \& FUTURE RESEARCH}

This paper has created a method using optimization to synthesize information on U.S. international trade, the Carload Waybill from the Surface Transportation Board, and economic information to estimate an international origin-destination table for containerized imports. The estimated origin-destination table is consistent with the PIERS international trade data, a gravity model for the transportation of international sea containers based on economic data, and impedance computed from travel time, and is nearly consistent with the STB Carload Waybill. The exponent on the distance term in the gravity model was optimized to be as consistent as possible with data in the model. This yielded a value of 1.2 for that exponent, which is similar to values obtained in other studies.

The primary limitation of the analysis described in this paper is the data quality. The PIERS international trade dataset is quite detailed and appears to be accurate, whereas the STB Carload Waybill has a few significant problems. First, there is no clear indication of which railcar flows actually originate or terminate at a port, and therefore the spatial distribution of the railcar flows from a port is unknown. We have inferred this based on the county that the waybill originated in and Leechman's estimate of rail share (2005). Second, for STCC 46, the STB Waybill does not appear to have accurate information on the number of containers; rather, it focuses on the number of railcars. We have estimated the number of containers from the number of railcars. Third, due to the practice of “rebilling," the STB Carload Waybill does not accurately capture true destinations of as much as $50 \%$ of the railcars we have associated with 
waterborne containerized imports. Finally, we have not integrated any information into the model pertaining to truck movements. There may be some opportunities to collect this data from the ports themselves. A few ports have focused on in-land transportation as part of defining their port development strategies.

This research can be extended in a few different directions. First, it is possible that additional data could be developed to augment the optimization. This data could be improvements to the types of data already included, or it could be the identification of new datasets to complement the data included. Second, the gravity model could be refined. Currently, we focus on aggregate measures of economic activity, but there is the opportunity to create other gravity models that might, potentially, be more representative of the demand for the transportation of waterborne sea containers. Third, there are a large number of solutions to this optimization model which have very similar values for the objective function. It could be interesting and useful to understand the patterns that exist in these solutions and possibly to develop a representation for the origin-destination table that is probabilistic based on these solutions. Fourth, the PEIRS data contains substantial information about the movements of individual commodities which could be effectively used if it could be complemented with other data at the commodity level. That other data could be in the form of demand models at the commodity level or on the spatial demand for those commodities inside the U.S. Finally, it is also important to develop an origindestination table for U.S. exports through container seaports. This analysis should be readily adaptable to the development of this table. 


\section{APPENDIX}

List of TAZs and Corresponding ID Number \& Estimated Origin-Destination Table for U.S. Imports of Waterborne Containerized Freight

\begin{tabular}{|c|c|}
\hline ID & TAZ Description \\
\hline 2 & Portland, ME \\
\hline 4 & Boston-Worcester-Lawrence-Lowell-Brockton, MA-NH-RI-VT \\
\hline 7 & Albany-Schenectady-Troy, NY \\
\hline 8 & Syracuse, NY-PA \\
\hline 9 & Rochester, NY-PA \\
\hline 10 & Buffalo-Niagara Falls, NY-PA \\
\hline 12 & New York-No. New Jersey-Long Island, NYNJ-CT-PA-MA-VT \\
\hline 16 & Pittsburgh, PA-WV \\
\hline 17 & Harrisburg-Lebanon-Carlisle, PA \\
\hline 18 & Philadelphia-Wilmington-Atlantic City, PANJ-DE-MD \\
\hline 19 & Washington-Baltimore, DC-MD-VA-WV-PA \\
\hline 21 & Charleston, WV-KY-OH \\
\hline 22 & Richmond-Petersburg, VA \\
\hline 23 & Norfolk-Virginia Beach-Newport News, VANC \\
\hline 24 & Greenville, NC \\
\hline 25 & Wilmington, NC-SC \\
\hline 27 & Raleigh-Durham-Chapel Hill, NC \\
\hline 28 & Greensboro-Winston-Salem-High Point, NCVA \\
\hline 29 & Charlotte-Gastonia-Rock Hill, NC-SC \\
\hline 31 & Greenville-Spartanburg-Anderson, SC-NC \\
\hline 32 & Columbia, SC \\
\hline 34 & Charleston-North Charleston, SC \\
\hline 36 & Atlanta, GA-AL-NC \\
\hline 39 & Savannah, GA-SC \\
\hline 41 & Jacksonville, FL-GA \\
\hline 42 & Orlando, FL \\
\hline 43 & Miami-Fort Lauderdale, FL \\
\hline 44 & Tampa-St. Petersburg-Clearwater, FL \\
\hline 47 & Mobile, AL \\
\hline 49 & Birmingham, AL \\
\hline 51 & Chattanooga, TN-GA \\
\hline 53 & Knoxville, TN \\
\hline 54 & Nashville, TN-KY \\
\hline 55 & Memphis, TN-AR-MS-KY \\
\hline 57 & Louisville, KY-IN \\
\hline 58 & Lexington, KY-TN-VA-WV \\
\hline 65 & Cleveland-Akron, OH-PA \\
\hline 66 & Columbus, $\mathrm{OH}$ \\
\hline
\end{tabular}




\begin{tabular}{|c|c|}
\hline 67 & Cincinnati-Hamilton, OH-KY-IN \\
\hline 68 & Dayton-Springfield, $\mathrm{OH}$ \\
\hline 70 & Toledo, $\mathrm{OH}$ \\
\hline 71 & Detroit-Ann Arbor-Flint, MI \\
\hline 73 & Grand Rapids-Muskegon-Holland, MI \\
\hline 76 & Fort Wayne, IN \\
\hline 79 & Indianapolis, IN-IL \\
\hline 83 & Chicago-Gary-Kenosha, IL-IN-WI \\
\hline 89 & Milwaukee-Racine, WI \\
\hline 94 & Green Bay, WI-MI \\
\hline 95 & Duluth-Superior, MN-WI \\
\hline 96 & Minneapolis-St. Paul, MN-WI-IA \\
\hline 104 & Des Moines, IA-IL-MO \\
\hline 105 & Kansas City, MO-KS \\
\hline 107 & St. Louis, MO-IL \\
\hline 108 & Springfield, MO \\
\hline 111 & Little Rock-North Little Rock, AR \\
\hline 112 & Jackson, MS-AL-LA \\
\hline 113 & New Orleans, LA-MS \\
\hline 122 & Houston-Galveston-Brazoria, TX \\
\hline 123 & Austin-San Marcos, TX \\
\hline 125 & Dallas-Fort Worth, TX-AR-OK \\
\hline 129 & San Antonio, TX \\
\hline 131 & Corpus Christi, TX \\
\hline 133 & El Paso, TX-NM \\
\hline 137 & Oklahoma City, OK \\
\hline 138 & Tulsa, OK-KS \\
\hline 139 & Wichita, KS-OK \\
\hline 143 & Omaha, NE-IA-MO \\
\hline 146 & Sioux Falls, SD-IA-MN-NE \\
\hline 152 & Fargo-Moorhead, ND-MN \\
\hline 153 & Billings, MT-WY \\
\hline 157 & Denver-Boulder-Greeley, CO-KS-NE \\
\hline 160 & Albuquerque, NM-AZ \\
\hline 162 & Phoenix-Mesa, AZ-NM \\
\hline 163 & Las Vegas, NV-AZ-UT \\
\hline 165 & Salt Lake City-Ogden, UT-ID \\
\hline 167 & Boise City, ID-OR \\
\hline 171 & Seattle-Tacoma-Bremerton, WA \\
\hline 172 & Portland-Salem, OR-WA \\
\hline 176 & San Francisco-Oakland-San Jose, CA \\
\hline 177 & Redding, CA-OR \\
\hline 178 & Sacramento-Yolo, CA \\
\hline 179 & Fresno, CA \\
\hline 180 & Los Angeles-Riverside-Orange County, CA-AZ \\
\hline 181 & San Diego, CA \\
\hline
\end{tabular}




\begin{tabular}{|c|c|c|c|c|c|c|c|}
\hline ORIGIN & 2 & 4 & 7 & 8 & 9 & 10 & 12 \\
\hline AMER. SAMOA & 35 & 320 & 53 & 47 & 43 & 53 & 1,085 \\
\hline ARGENTINA & 275 & 2,468 & 397 & 343 & 305 & 363 & 8,274 \\
\hline AUSTRALIA & 285 & 2,584 & 428 & 378 & 343 & 426 & 8,761 \\
\hline AUSTRIA & 262 & 2,329 & 370 & 303 & 260 & 307 & 7,438 \\
\hline BAHAMAS & 53 & 483 & 84 & 70 & 60 & 73 & 1,957 \\
\hline BANGLADESH & 246 & 2,206 & 357 & 307 & 273 & 326 & 7,212 \\
\hline BELGIUM & 994 & 8,735 & 1,386 & 1,156 & 991 & 1,165 & 28,461 \\
\hline BRAZIL & 2,062 & 18,734 & 3,000 & 2,520 & 2,220 & 2,629 & 64,640 \\
\hline CAMBODIA & 93 & 841 & 139 & 122 & 110 & 137 & 2,848 \\
\hline CANADA & 38 & 351 & 59 & 52 & 47 & 62 & 1,265 \\
\hline CHILE & 554 & 5,083 & 863 & 741 & 677 & 856 & 18,140 \\
\hline CHINA MNLND & 19,289 & 175,451 & 28,982 & 25,441 & 23,196 & 28,809 & 598,111 \\
\hline CHINA TWN & 1,897 & 17,259 & 2,851 & 2,503 & 2,282 & 2,834 & 58,834 \\
\hline COLOMBIA & 318 & 2,901 & 500 & 417 & 357 & 432 & 11,243 \\
\hline COSTA RICA & 524 & 4,804 & 839 & 691 & 596 & 722 & 19,443 \\
\hline CZECH REP & 110 & 979 & 156 & 127 & 110 & 129 & 3,128 \\
\hline DENMARK & 237 & 2,083 & 334 & 272 & 233 & 275 & 6,656 \\
\hline DOM. REP & 320 & 2,872 & 490 & 405 & 344 & 408 & 11,231 \\
\hline ECUADOR & 282 & 2,606 & 447 & 378 & 350 & 448 & 9,518 \\
\hline EGYPT & 116 & 1,026 & 166 & 140 & 122 & 145 & 3,356 \\
\hline EL SALVADOR & 133 & 1,230 & 211 & 180 & 165 & 211 & 4,492 \\
\hline FINLAND & 163 & 1,452 & 232 & 190 & 165 & 196 & 4,622 \\
\hline FRANCE & 1,034 & 9,077 & 1,454 & 1,198 & 1,025 & 1,216 & 29,566 \\
\hline GERMANY & 2,630 & 23,375 & 3,713 & 3,043 & 2,614 & 3,078 & 74,659 \\
\hline GREECE & 106 & 945 & 151 & 127 & 111 & 131 & 3,064 \\
\hline GUATEMALA & 440 & 4,055 & 695 & 594 & 544 & 696 & 14,788 \\
\hline HAITI & 43 & 390 & 68 & 56 & 48 & 59 & 1,579 \\
\hline HONDURAS & 485 & 4,473 & 767 & 655 & 600 & 768 & 16,314 \\
\hline HONG KONG & 3,668 & 33,332 & 5,503 & 4,830 & 4,400 & 5,454 & 113,342 \\
\hline ICELAND & 27 & 237 & 38 & 31 & 26 & 30 & 770 \\
\hline INDIA & 1,309 & 11,651 & 1,892 & 1,618 & 1,426 & 1,711 & 38,204 \\
\hline INDONESIA & 982 & 8,764 & 1,435 & 1,260 & 1,146 & 1,415 & 29,460 \\
\hline IRELAND & 137 & 1,217 & 192 & 158 & 136 & 160 & 3,914 \\
\hline ISRAEL & 453 & 4,018 & 649 & 548 & 478 & 570 & 13,143 \\
\hline ITALY & 2,423 & 21,570 & 3,442 & 2,873 & 2,503 & 2,957 & 69,810 \\
\hline IVORY COAST & 42 & 372 & 59 & 51 & 44 & 52 & 1,225 \\
\hline JAMAICA & 39 & 361 & 63 & 52 & 45 & 54 & 1,460 \\
\hline JAPAN & 2,392 & 21,798 & 3,605 & 3,165 & 2,891 & 3,623 & 74,680 \\
\hline MALAYSIA & 974 & 8,684 & 1,412 & 1,214 & 1,074 & 1,290 & 28,497 \\
\hline MEXICO & 78 & 722 & 128 & 105 & 93 & 125 & 2,862 \\
\hline NETHERLANDS & 1,247 & 11,086 & 1,760 & 1,455 & 1,260 & 1,482 & 35,756 \\
\hline NEW ZEALAND & 235 & 2,135 & 354 & 313 & 284 & 354 & 7,261 \\
\hline NICARAGUA & 76 & 698 & 120 & 102 & 94 & 122 & 2,559 \\
\hline NORWAY & 113 & 990 & 159 & 128 & 110 & 130 & 3,156 \\
\hline OMAN & 21 & 186 & 30 & 26 & 23 & 27 & 609 \\
\hline PAKISTAN & 414 & 3,705 & 599 & 514 & 453 & 541 & 12,146 \\
\hline PANAMA & 54 & 493 & 86 & 71 & 62 & 75 & 1,879 \\
\hline PERU & 117 & 1,077 & 184 & 156 & 143 & 183 & 3,887 \\
\hline PHILIPPINES & 470 & 4,251 & 704 & 618 & 561 & 698 & 14,446 \\
\hline POLAND & 200 & 1,778 & 283 & 233 & 201 & 237 & 5,689 \\
\hline PORTUGAL & 184 & 1,635 & 258 & 214 & 182 & 214 & 5,319 \\
\hline RUSSIA & 179 & 1,579 & 254 & 208 & 179 & 214 & 5,060 \\
\hline SINGAPORE & 268 & 2,388 & 388 & 341 & 310 & 383 & 7,975 \\
\hline SOUTH AFRICA & 292 & 2,607 & 418 & 360 & 321 & 379 & 8,630 \\
\hline SOUTH KOREA & 1,624 & 14,784 & 2,443 & 2,145 & 1,957 & 2,435 & 50,512 \\
\hline SPAIN & 860 & 7,625 & 1,204 & 998 & 850 & 996 & 24,808 \\
\hline SRI LANKA & 181 & 1,617 & 262 & 224 & 199 & 237 & 5,280 \\
\hline SWEDEN & 396 & 3,480 & 558 & 453 & 390 & 463 & 11,116 \\
\hline SWITZERLAND & 106 & 945 & 150 & 123 & 106 & 124 & 3,020 \\
\hline THAILAND & 1,388 & 12,595 & 2,077 & 1,823 & 1,652 & 2,048 & 42,640 \\
\hline TRINIDAD & 23 & 211 & 35 & 29 & 25 & 30 & 772 \\
\hline TURKEY & 638 & 5,685 & 911 & 767 & 671 & 796 & 18,453 \\
\hline UNITED ARAB & 95 & 852 & 138 & 118 & 104 & 125 & 2,783 \\
\hline UK & 1,122 & 9,961 & 1,576 & 1,294 & 1,116 & 1,309 & 32,048 \\
\hline US VIRGIN IS & 22 & 201 & 35 & 29 & 25 & 30 & 814 \\
\hline VENEZUELA & 192 & 1,758 & 293 & 244 & 213 & 253 & 6,570 \\
\hline VIETNAM & 575 & 5,220 & 861 & 756 & 688 & 851 & 17,701 \\
\hline
\end{tabular}




\begin{tabular}{|c|c|c|c|c|c|c|c|}
\hline ORIGIN & 16 & 17 & 18 & 19 & 21 & 22 & 23 \\
\hline AMER. SAMOA & 100 & 56 & 271 & 414 & 53 & 52 & 57 \\
\hline ARGENTINA & 695 & 407 & 2,017 & 3,037 & 379 & 381 & 420 \\
\hline AUSTRALIA & 810 & 448 & 2,181 & 3,330 & 431 & 417 & 455 \\
\hline AUSTRIA & 566 & 342 & 1,736 & 2,514 & 302 & 308 & 339 \\
\hline BAHAMAS & 150 & 94 & 518 & 735 & 95 & 100 & 113 \\
\hline BANGLADESH & 615 & 355 & 1,750 & 2,626 & 324 & 323 & 356 \\
\hline BELGIUM & 2,188 & 1,327 & 6,694 & 9,661 & 1,157 & 1,184 & 1,317 \\
\hline BRAZIL & 5,145 & 3,087 & 15,852 & 23,187 & 2,880 & 2,976 & 3,319 \\
\hline CAMBODIA & 260 & 144 & 706 & 1,074 & 135 & 131 & 142 \\
\hline CANADA & 120 & 64 & 321 & 481 & 61 & 58 & 61 \\
\hline CHILE & 1,659 & 918 & 4,622 & 6,975 & 934 & 896 & 971 \\
\hline CHINA MNLND & 54,850 & 30,405 & 148,630 & 225,775 & 28,618 & 27,538 & 29,695 \\
\hline CHINA TWN & 5,395 & 2,991 & 14,620 & 22,209 & 2,815 & 2,709 & 2,921 \\
\hline COLOMBIA & 876 & 548 & 2,926 & 4,225 & 541 & 561 & 618 \\
\hline COSTA RICA & 1,488 & 937 & 5,152 & 7,307 & 942 & 994 & 1,126 \\
\hline CZECH REP & 238 & 144 & 730 & 1,057 & 127 & 130 & 143 \\
\hline DENMARK & 508 & 306 & 1,555 & 2,253 & 271 & 274 & 304 \\
\hline DOM. REP & 835 & 520 & 2,887 & 4,125 & 507 & 555 & 612 \\
\hline ECUADOR & 875 & 482 & 2,454 & 3,686 & 503 & 480 & 513 \\
\hline EGYPT & 272 & 161 & 806 & 1,178 & 144 & 145 & 161 \\
\hline EL SALVADOR & 413 & 227 & 1,158 & 1,740 & 238 & 227 & 245 \\
\hline FINLAND & 364 & 217 & 1,087 & 1,588 & 192 & 195 & 214 \\
\hline FRANCE & 2,260 & 1,374 & 6,944 & 10,001 & 1,196 & 1,238 & 1,364 \\
\hline GERMANY & 5,681 & 3,430 & 17,427 & 25,234 & 3,030 & 3,091 & 3,407 \\
\hline GREECE & 246 & 146 & 735 & 1,077 & 131 & 133 & 146 \\
\hline GUATEMALA & 1,359 & 748 & 3,810 & 5,723 & 781 & 745 & 804 \\
\hline HAITI & 121 & 76 & 418 & 593 & 76 & 81 & 91 \\
\hline HONDURAS & 1,499 & 826 & 4,203 & 6,314 & 861 & 822 & 887 \\
\hline HONG KONG & 10,380 & 5,760 & 28,138 & 42,770 & 5,418 & 5,218 & 5,636 \\
\hline ICELAND & 55 & 34 & 176 & 250 & 29 & 29 & 33 \\
\hline INDIA & 3,217 & 1,868 & 9,248 & 13,816 & 1,700 & 1,693 & 1,873 \\
\hline INDONESIA & 2,691 & 1,491 & 7,300 & 11,110 & 1,401 & 1,356 & 1,469 \\
\hline IRELAND & 297 & 181 & 927 & 1,330 & 159 & 163 & 182 \\
\hline ISRAEL & 1,068 & 631 & 3,159 & 4,655 & 567 & 570 & 633 \\
\hline ITALY & 5,519 & 3,304 & 16,687 & 24,334 & 2,938 & 3,005 & 3,312 \\
\hline IVORY COAST & 99 & 59 & 296 & 436 & 54 & 55 & 61 \\
\hline JAMAICA & 112 & 70 & 387 & 549 & 71 & 75 & 85 \\
\hline JAPAN & 6,866 & 3,799 & 18,594 & 28,208 & 3,580 & 3,438 & 3,696 \\
\hline MALAYSIA & 2,445 & 1,402 & 6,890 & 10,340 & 1,281 & 1,271 & 1,406 \\
\hline MEXICO & 249 & 140 & 742 & 1,116 & 161 & 151 & 160 \\
\hline NETHERLANDS & 2,759 & 1,671 & 8,504 & 12,285 & 1,473 & 1,505 & 1,675 \\
\hline NEW ZEALAND & 673 & 372 & 1,817 & 2,762 & 359 & 347 & 378 \\
\hline NICARAGUA & 235 & 129 & 661 & 1,003 & 136 & 130 & 140 \\
\hline NORWAY & 238 & 144 & 735 & 1,061 & 127 & 129 & 143 \\
\hline OMAN & 51 & 30 & 147 & 219 & 27 & 27 & 30 \\
\hline PAKISTAN & 1,022 & 594 & 2,927 & 4,371 & 540 & 538 & 593 \\
\hline PANAMA & 151 & 92 & 486 & 706 & 94 & 93 & 104 \\
\hline PERU & 353 & 197 & 996 & 1,500 & 203 & 192 & 208 \\
\hline PHILIPPINES & 1,328 & 734 & 3,585 & 5,451 & 690 & 665 & 719 \\
\hline POLAND & 437 & 263 & 1,332 & 1,935 & 231 & 235 & 259 \\
\hline PORTUGAL & 397 & 243 & 1,244 & 1,783 & 212 & 218 & 243 \\
\hline RUSSIA & 392 & 235 & 1,188 & 1,730 & 209 & 210 & 234 \\
\hline SINGAPORE & 729 & 405 & 1,977 & 3,008 & 379 & 367 & 398 \\
\hline SOUTH AFRICA & 725 & 424 & 2,095 & 3,146 & 391 & 391 & 433 \\
\hline SOUTH KOREA & 4,638 & 2,557 & 12,563 & 19,073 & 2,408 & 2,315 & 2,504 \\
\hline SPAIN & 1,848 & 1,131 & 5,802 & 8,307 & 989 & 1,018 & 1,121 \\
\hline SRI LANKA & 446 & 259 & 1,279 & 1,914 & 236 & 235 & 259 \\
\hline SWEDEN & 847 & 516 & 2,596 & 3,760 & 452 & 456 & 508 \\
\hline SWITZERLAND & 230 & 139 & 705 & 1,021 & 123 & 125 & 138 \\
\hline THAILAND & 3,896 & 2,158 & 10,568 & 16,082 & 2,028 & 1,956 & 2,126 \\
\hline TRINIDAD & 59 & 36 & 193 & 280 & 35 & 37 & 41 \\
\hline TURKEY & 1,489 & 883 & 4,429 & 6,509 & 791 & 803 & 885 \\
\hline UNITED ARAB & 234 & 136 & 674 & 1,006 & 124 & 124 & 136 \\
\hline UK & 2,432 & 1,484 & 7,596 & 10,903 & 1,301 & 1,336 & 1,488 \\
\hline US VIRGIN IS & 62 & 39 & 216 & 306 & 39 & 42 & 47 \\
\hline VENEZUELA & 513 & 314 & 1,675 & 2,423 & 310 & 321 & 361 \\
\hline
\end{tabular}




\begin{tabular}{|c|c|c|c|c|c|c|c|}
\hline VIETNAM & 1,619 & 899 & 4,389 & 6,677 & 845 & 815 & 882 \\
\hline ORIGIN & 24 & 25 & 27 & 28 & 29 & 31 & 32 \\
\hline AMER. SAMOA & 21 & 22 & 82 & 52 & 77 & 61 & 44 \\
\hline ARGENTINA & 150 & 157 & 578 & 359 & 538 & 414 & 310 \\
\hline AUSTRALIA & 169 & 178 & 655 & 417 & 621 & 488 & 356 \\
\hline AUSTRIA & 120 & 119 & 459 & 277 & 405 & 305 & 229 \\
\hline BAHAMAS & 41 & 47 & 168 & 103 & 166 & 133 & 111 \\
\hline BANGLADESH & 128 & 130 & 492 & 306 & 449 & 343 & 254 \\
\hline BELGIUM & 463 & 457 & 1,777 & 1,071 & 1,565 & 1,177 & 885 \\
\hline BRAZIL & 1,157 & 1,239 & 4,546 & 2,741 & 4,182 & 3,269 & 2,511 \\
\hline CAMBODIA & 52 & 53 & 198 & 125 & 185 & 145 & 106 \\
\hline CANADA & 22 & 21 & 83 & 52 & 75 & 61 & 43 \\
\hline CHILE & 369 & 395 & 1,442 & 926 & 1,400 & 1,110 & 806 \\
\hline CHINA MNLND & 10,801 & 11,078 & 41,470 & 25,966 & 38,769 & 30,343 & 22,214 \\
\hline CHINA TWN & 1,062 & 1,090 & 4,079 & 2,554 & 3,814 & 2,985 & 2,185 \\
\hline COLOMBIA & 226 & 254 & 904 & 571 & 899 & 711 & 573 \\
\hline COSTA RICA & 411 & 464 & 1,672 & 1,026 & 1,652 & 1,317 & 1,102 \\
\hline CZECH REP & 50 & 50 & 193 & 117 & 170 & 128 & 96 \\
\hline DENMARK & 106 & 106 & 412 & 247 & 364 & 274 & 204 \\
\hline DOM. REP & 218 & 243 & 880 & 517 & 819 & 633 & 514 \\
\hline ECUADOR & 200 & 216 & 784 & 506 & 773 & 618 & 447 \\
\hline EGYPT & 57 & 57 & 220 & 134 & 197 & 149 & 112 \\
\hline EL SALVADOR & 94 & 102 & 370 & 239 & 365 & 292 & 211 \\
\hline FINLAND & 76 & 76 & 292 & 177 & 259 & 196 & 147 \\
\hline FRANCE & 479 & 472 & 1,838 & 1,106 & 1,615 & 1,213 & 913 \\
\hline GERMANY & 1,200 & 1,198 & 4,607 & 2,785 & 4,069 & 3,065 & 2,302 \\
\hline GREECE & 52 & 52 & 200 & 122 & 178 & 135 & 101 \\
\hline GUATEMALA & 310 & 335 & 1,215 & 784 & 1,196 & 957 & 692 \\
\hline HAITI & 33 & 38 & 136 & 83 & 134 & 107 & 89 \\
\hline HONDURAS & 342 & 369 & 1,340 & 865 & 1,319 & 1,055 & 764 \\
\hline HONG KONG & 2,051 & 2,105 & 7,874 & 4,933 & 7,329 & 5,754 & 4,195 \\
\hline ICELAND & 11 & 11 & 44 & 26 & 38 & 28 & 21 \\
\hline INDIA & 673 & 682 & 2,583 & 1,598 & 2,346 & 1,790 & 1,327 \\
\hline INDONESIA & 533 & 559 & 2,061 & 1,310 & 1,951 & 1,523 & 1,115 \\
\hline IRELAND & 63 & 62 & 244 & 145 & 214 & 160 & 120 \\
\hline ISRAEL & 224 & 226 & 865 & 526 & 776 & 588 & 439 \\
\hline ITALY & 1,171 & 1,165 & 4,498 & 2,732 & 3,996 & 3,018 & 2,260 \\
\hline IVORY COAST & 21 & 22 & 83 & 50 & 75 & 57 & 43 \\
\hline JAMAICA & 31 & 35 & 126 & 77 & 124 & 99 & 83 \\
\hline JAPAN & 1,344 & 1,376 & 5,158 & 3,226 & 4,825 & 3,784 & 2,770 \\
\hline MALAYSIA & 505 & 515 & 1,938 & 1,203 & 1,773 & 1,361 & 1,003 \\
\hline MEXICO & 66 & 75 & 265 & 167 & 265 & 215 & 170 \\
\hline NETHERLANDS & 583 & 582 & 2,261 & 1,351 & 1,992 & 1,499 & 1,117 \\
\hline NEW ZEALAND & 141 & 149 & 548 & 347 & 521 & 408 & 297 \\
\hline NICARAGUA & 54 & 59 & 212 & 137 & 210 & 168 & 123 \\
\hline NORWAY & 50 & 50 & 193 & 116 & 170 & 128 & 96 \\
\hline OMAN & 11 & 11 & 41 & 25 & 37 & 28 & 21 \\
\hline PAKISTAN & 213 & 216 & 817 & 505 & 742 & 566 & 420 \\
\hline PANAMA & 39 & 43 & 155 & 98 & 153 & 121 & 97 \\
\hline PERU & 80 & 86 & 314 & 200 & 307 & 245 & 177 \\
\hline PHILIPPINES & 261 & 272 & 1,004 & 637 & 949 & 742 & 543 \\
\hline POLAND & 91 & 92 & 351 & 213 & 311 & 235 & 176 \\
\hline PORTUGAL & 84 & 84 & 323 & 194 & 286 & 212 & 160 \\
\hline RUSSIA & 83 & 82 & 317 & 192 & 281 & 213 & 159 \\
\hline SINGAPORE & 145 & 149 & 556 & 349 & 519 & 405 & 297 \\
\hline SOUTH AFRICA & 155 & 161 & 596 & 369 & 555 & 424 & 317 \\
\hline SOUTH KOREA & 906 & 933 & 3,496 & 2,188 & 3,255 & 2,561 & 1,866 \\
\hline SPAIN & 392 & 385 & 1,506 & 903 & 1,318 & 988 & 745 \\
\hline SRI LANKA & 93 & 95 & 358 & 222 & 326 & 249 & 184 \\
\hline SWEDEN & 179 & 177 & 687 & 415 & 607 & 457 & 343 \\
\hline SWITZERLAND & 49 & 48 & 186 & 113 & 165 & 124 & 93 \\
\hline THAILAND & 771 & 798 & 2,962 & 1,864 & 2,776 & 2,167 & 1,587 \\
\hline TRINIDAD & 14 & 16 & 57 & 35 & 54 & 43 & 33 \\
\hline TURKEY & 315 & 315 & 1,208 & 738 & 1,080 & 819 & 611 \\
\hline UNITED ARAB & 49 & 50 & 188 & 116 & 171 & 130 & 97 \\
\hline UK & 516 & 512 & 1,980 & 1,189 & 1,753 & 1,303 & 982 \\
\hline US VIRGIN IS & 17 & 19 & 70 & 43 & 69 & 55 & 46 \\
\hline VENEZUELA & 129 & 145 & 516 & 326 & 512 & 405 & 325 \\
\hline VIETNAM & 321 & 331 & 1,232 & 773 & 1,151 & 903 & 658 \\
\hline
\end{tabular}




\begin{tabular}{|c|c|c|c|c|c|c|c|}
\hline ORIGIN & 34 & 36 & 39 & 41 & 42 & 43 & 44 \\
\hline AMER. SAMOA & 19 & 266 & 20 & 95 & 111 & 183 & 125 \\
\hline ARGENTINA & 134 & 1,789 & 141 & 672 & 784 & 1,343 & 882 \\
\hline AUSTRALIA & 151 & 2,135 & 160 & 760 & 892 & 1,477 & 1,008 \\
\hline AUSTRIA & 101 & 1,279 & 101 & 459 & 530 & 901 & 589 \\
\hline BAHAMAS & 47 & 640 & 55 & 314 & 318 & 564 & 335 \\
\hline BANGLADESH & 109 & 1,445 & 113 & 518 & 614 & 1,042 & 693 \\
\hline BELGIUM & 385 & 4,883 & 389 & 1,753 & 2,018 & 3,465 & 2,241 \\
\hline BRAZIL & 1,090 & 14,488 & 1,156 & 5,787 & 6,517 & 11,236 & 7,237 \\
\hline CAMBODIA & 45 & 633 & 48 & 225 & 265 & 439 & 299 \\
\hline CANADA & 19 & 273 & 20 & 97 & 109 & 172 & 122 \\
\hline CHILE & 347 & 5,135 & 367 & 1,827 & 2,218 & 3,670 & 2,600 \\
\hline CHINA MNLND & 9,445 & 133,974 & 9,986 & 47,671 & 55,814 & 91,747 & 62,733 \\
\hline CHINA TWN & 929 & 13,179 & 982 & 4,689 & 5,490 & 9,025 & 6,171 \\
\hline COLOMBIA & 242 & 3,304 & 275 & 1,508 & 1,569 & 2,746 & 1,694 \\
\hline COSTA RICA & 466 & 6,357 & 546 & 3,121 & 3,161 & 5,604 & 3,332 \\
\hline CZECH REP & 42 & 538 & 42 & 193 & 223 & 379 & 248 \\
\hline DENMARK & 89 & 1,139 & 91 & 412 & 476 & 810 & 529 \\
\hline DOM. REP & 230 & 2,967 & 256 & 1,389 & 1,423 & 2,576 & 1,529 \\
\hline ECUADOR & 192 & 2,925 & 206 & 1,041 & 1,268 & 2,102 & 1,525 \\
\hline EGYPT & 48 & 627 & 49 & 226 & 264 & 449 & 295 \\
\hline EL SALVADOR & 92 & 1,399 & 97 & 498 & 607 & 992 & 720 \\
\hline FINLAND & 64 & 817 & 65 & 295 & 344 & 586 & 384 \\
\hline FRANCE & 398 & 5,034 & 402 & 1,807 & 2,079 & 3,569 & 2,307 \\
\hline GERMANY & 1,009 & 12,838 & 1,012 & 4,606 & 5,316 & 9,047 & 5,910 \\
\hline GREECE & 44 & 566 & 45 & 204 & 239 & 404 & 267 \\
\hline GUATEMALA & 300 & 4,574 & 318 & 1,627 & 1,983 & 3,246 & 2,351 \\
\hline HAITI & 38 & 516 & 44 & 253 & 257 & 455 & 271 \\
\hline HONDURAS & 331 & 5,046 & 351 & 1,795 & 2,188 & 3,581 & 2,594 \\
\hline HONG KONG & 1,783 & 25,215 & 1,892 & 8,972 & 10,527 & 17,419 & 11,892 \\
\hline ICELAND & 9 & 113 & 9 & 41 & 47 & 80 & 52 \\
\hline INDIA & 571 & 7,532 & 589 & 2,702 & 3,197 & 5,420 & 3,598 \\
\hline INDONESIA & 474 & 6,642 & 500 & 2,372 & 2,792 & 4,622 & 3,147 \\
\hline IRELAND & 53 & 664 & 53 & 239 & 271 & 462 & 301 \\
\hline ISRAEL & 190 & 2,470 & 195 & 890 & 1,038 & 1,767 & 1,162 \\
\hline ITALY & 987 & 12,651 & 1,003 & 4,570 & 5,334 & 9,012 & 5,943 \\
\hline IVORY COAST & 19 & 242 & 19 & 91 & 105 & 181 & 118 \\
\hline JAMAICA & 35 & 477 & 41 & 234 & 237 & 421 & 250 \\
\hline JAPAN & 1,179 & 16,817 & 1,248 & 5,984 & 6,978 & 11,413 & 7,828 \\
\hline MALAYSIA & 429 & 5,947 & 446 & 2,116 & 2,493 & 4,130 & 2,810 \\
\hline MEXICO & 74 & 1,163 & 84 & 456 & 548 & 847 & 693 \\
\hline NETHERLANDS & 490 & 6,221 & 495 & 2,233 & 2,573 & 4,379 & 2,858 \\
\hline NEW ZEALAND & 126 & 1,792 & 134 & 638 & 747 & 1,233 & 843 \\
\hline NICARAGUA & 53 & 812 & 56 & 289 & 352 & 575 & 419 \\
\hline NORWAY & 42 & 532 & 42 & 193 & 222 & 378 & 246 \\
\hline OMAN & 9 & 119 & 9 & 43 & 50 & 86 & 57 \\
\hline PAKISTAN & 181 & 2,382 & 186 & 858 & 1,011 & 1,714 & 1,138 \\
\hline PANAMA & 41 & 558 & 47 & 248 & 276 & 469 & 349 \\
\hline PERU & 76 & 1,137 & 81 & 405 & 492 & 810 & 587 \\
\hline PHILIPPINES & 231 & 3,265 & 244 & 1,162 & 1,363 & 2,247 & 1,534 \\
\hline POLAND & 77 & 983 & 77 & 356 & 411 & 700 & 458 \\
\hline PORTUGAL & 71 & 897 & 71 & 322 & 373 & 635 & 413 \\
\hline RUSSIA & 69 & 884 & 70 & 319 & 373 & 630 & 415 \\
\hline SINGAPORE & 126 & 1,774 & 133 & 631 & 743 & 1,230 & 837 \\
\hline SOUTH AFRICA & 136 & 1,819 & 143 & 678 & 794 & 1,366 & 895 \\
\hline SOUTH KOREA & 794 & 11,287 & 844 & 4,016 & 4,694 & 7,735 & 5,272 \\
\hline SPAIN & 329 & 4,133 & 327 & 1,500 & 1,718 & 2,952 & 1,902 \\
\hline SRI LANKA & 79 & 1,047 & 82 & 375 & 445 & 754 & 501 \\
\hline SWEDEN & 149 & 1,899 & 151 & 687 & 799 & 1,361 & 889 \\
\hline SWITZERLAND & 41 & 519 & 41 & 186 & 215 & 366 & 239 \\
\hline THAILAND & 674 & 9,482 & 711 & 3,374 & 3,972 & 6,575 & 4,476 \\
\hline TRINIDAD & 15 & 190 & 16 & 82 & 89 & 157 & 97 \\
\hline TURKEY & 266 & 3,436 & 271 & 1,238 & 1,452 & 2,455 & 1,622 \\
\hline UNITED ARAB & 42 & 548 & 43 & 197 & 233 & 395 & 262 \\
\hline UK & 432 & 5,451 & 436 & 1,958 & 2,247 & 3,825 & 2,491 \\
\hline US VIRGIN IS & 20 & 266 & 23 & 131 & 132 & 235 & 139 \\
\hline VENEZUELA & 138 & 1,830 & 155 & 822 & 886 & 1,549 & 936 \\
\hline VIETNAM & 280 & 3,943 & 296 & 1,403 & 1,650 & 2,736 & 1,858 \\
\hline
\end{tabular}




\begin{tabular}{|c|c|c|c|c|c|c|c|}
\hline ORIGIN & 47 & 49 & 51 & 53 & 54 & 55 & 57 \\
\hline AMER. SAMOA & 51 & 114 & 21 & 43 & 93 & 91 & 73 \\
\hline ARGENTINA & 323 & 756 & 136 & 282 & 594 & 556 & 462 \\
\hline AUSTRALIA & 410 & 917 & 166 & 346 & 750 & 726 & 592 \\
\hline AUSTRIA & 216 & 511 & 110 & 217 & 413 & 377 & 343 \\
\hline BAHAMAS & 109 & 261 & 27 & 80 & 155 & 143 & 107 \\
\hline BANGLADESH & 257 & 597 & 123 & 241 & 495 & 461 & 400 \\
\hline BELGIUM & 820 & 1,960 & 425 & 827 & 1,569 & 1,442 & 1,295 \\
\hline BRAZIL & 2,584 & 6,122 & 974 & 2,170 & 4,471 & 4,161 & 3,387 \\
\hline CAMBODIA & 121 & 270 & 53 & 103 & 229 & 216 & 183 \\
\hline CANADA & 58 & 121 & 25 & 45 & 109 & 99 & 90 \\
\hline CHILE & 1,025 & 2,233 & 342 & 780 & 1,710 & 1,715 & 1,296 \\
\hline CHINA MNLND & 25,877 & 57,382 & 11,303 & 21,522 & 48,441 & 45,783 & 38,868 \\
\hline CHINA TWN & 2,545 & 5,644 & 1,112 & 2,117 & 4,765 & 4,504 & 3,823 \\
\hline COLOMBIA & 575 & 1,396 & 162 & 448 & 888 & 852 & 645 \\
\hline COSTA RICA & 1,085 & 2,594 & 265 & 798 & 1,545 & 1,417 & 1,068 \\
\hline CZECH REP & 91 & 215 & 46 & 91 & 174 & 159 & 144 \\
\hline DENMARK & 195 & 455 & 100 & 193 & 369 & 337 & 308 \\
\hline DOM. REP & 514 & 1,253 & 153 & 395 & 779 & 733 & 563 \\
\hline ECUADOR & 615 & 1,304 & 182 & 435 & 959 & 986 & 713 \\
\hline EGYPT & 109 & 254 & 53 & 105 & 207 & 191 & 168 \\
\hline EL SALVADOR & 290 & 616 & 86 & 205 & 453 & 465 & 337 \\
\hline FINLAND & 141 & 331 & 71 & 138 & 268 & 247 & 223 \\
\hline FRANCE & 850 & 2,017 & 439 & 853 & 1,613 & 1,481 & 1,332 \\
\hline GERMANY & 2,164 & 5,124 & 1,106 & 2,173 & 4,147 & 3,785 & 3,443 \\
\hline GREECE & 98 & 228 & 49 & 95 & 185 & 171 & 152 \\
\hline GUATEMALA & 946 & 2,011 & 282 & 673 & 1,483 & 1,522 & 1,104 \\
\hline HAITI & 88 & 211 & 22 & 65 & 125 & 115 & 87 \\
\hline HONDURAS & 1,043 & 2,218 & 311 & 742 & 1,636 & 1,679 & 1,218 \\
\hline HONG KONG & 4,848 & 10,833 & 2,136 & 4,079 & 9,149 & 8,644 & 7,338 \\
\hline ICELAND & 19 & 45 & 11 & 20 & 38 & 34 & 32 \\
\hline INDIA & 1,333 & 3,095 & 640 & 1,259 & 2,554 & 2,376 & 2,064 \\
\hline INDONESIA & 1,273 & 2,847 & 552 & 1,079 & 2,363 & 2,263 & 1,894 \\
\hline IRELAND & 110 & 263 & 58 & 113 & 212 & 192 & 175 \\
\hline ISRAEL & 431 & 1,002 & 210 & 414 & 816 & 755 & 663 \\
\hline ITALY & 2,181 & 5,116 & 1,087 & 2,122 & 4,102 & 3,781 & 3,368 \\
\hline IVORY COAST & 43 & 101 & 19 & 39 & 79 & 73 & 61 \\
\hline JAMAICA & 81 & 195 & 20 & 60 & 116 & 106 & 80 \\
\hline JAPAN & 3,276 & 7,218 & 1,420 & 2,687 & 6,089 & 5,759 & 4,889 \\
\hline MALAYSIA & 1,134 & 2,539 & 501 & 966 & 2,146 & 2,026 & 1,720 \\
\hline MEXICO & 303 & 560 & 53 & 151 & 342 & 392 & 236 \\
\hline NETHERLANDS & 1,046 & 2,478 & 541 & 1,054 & 2,002 & 1,826 & 1,651 \\
\hline NEW ZEALAND & 346 & 771 & 138 & 289 & 628 & 613 & 495 \\
\hline NICARAGUA & 170 & 358 & 49 & 118 & 261 & 270 & 196 \\
\hline NORWAY & 90 & 212 & 47 & 90 & 171 & 157 & 144 \\
\hline OMAN & 21 & 49 & 10 & 20 & 40 & 37 & 33 \\
\hline PAKISTAN & 422 & 982 & 203 & 398 & 807 & 751 & 655 \\
\hline PANAMA & 118 & 236 & 28 & 77 & 159 & 172 & 114 \\
\hline PERU & 234 & 503 & 73 & 172 & 378 & 379 & 284 \\
\hline PHILIPPINES & 628 & 1,397 & 272 & 526 & 1,165 & 1,110 & 938 \\
\hline POLAND & 168 & 394 & 85 & 166 & 320 & 292 & 267 \\
\hline PORTUGAL & 151 & 355 & 78 & 151 & 282 & 257 & 234 \\
\hline RUSSIA & 152 & 357 & 77 & 149 & 288 & 266 & 240 \\
\hline SINGAPORE & 339 & 758 & 150 & 287 & 640 & 604 & 513 \\
\hline SOUTH AFRICA & 331 & 768 & 143 & 290 & 614 & 575 & 477 \\
\hline SOUTH KOREA & 2,188 & 4,839 & 953 & 1,818 & 4,103 & 3,879 & 3,293 \\
\hline SPAIN & 694 & 1,634 & 361 & 695 & 1,301 & 1,193 & 1,087 \\
\hline SRI LANKA & 186 & 431 & 89 & 175 & 356 & 331 & 289 \\
\hline SWEDEN & 326 & 765 & 166 & 321 & 614 & 565 & 514 \\
\hline SWITZERLAND & 88 & 207 & 45 & 88 & 168 & 153 & 139 \\
\hline THAILAND & 1,810 & 4,049 & 796 & 1,540 & 3,422 & 3,231 & 2,743 \\
\hline TRINIDAD & 34 & 80 & 11 & 27 & 55 & 51 & 40 \\
\hline TURKEY & 597 & 1,389 & 294 & 576 & 1,129 & 1,044 & 924 \\
\hline UNITED ARAB & 97 & 226 & 47 & 92 & 186 & 173 & 151 \\
\hline UK & 910 & 2,160 & 471 & 925 & 1,738 & 1,580 & 1,437 \\
\hline US VIRGIN IS & 45 & 109 & 11 & 33 & 65 & 59 & 45 \\
\hline VENEZUELA & 327 & 773 & 94 & 251 & 509 & 470 & 364 \\
\hline VIETNAM & 755 & 1,685 & 332 & 639 & 1,423 & 1,344 & 1,141 \\
\hline
\end{tabular}




\begin{tabular}{|c|c|c|c|c|c|c|c|}
\hline ORIGIN & 58 & 65 & 66 & 67 & 68 & 70 & 71 \\
\hline AMER. SAMOA & 41 & 142 & 79 & 77 & 35 & 38 & 250 \\
\hline ARGENTINA & 261 & 940 & 513 & 499 & 222 & 238 & 1,551 \\
\hline AUSTRALIA & 326 & 1,144 & 637 & 623 & 284 & 305 & 2,011 \\
\hline AUSTRIA & 191 & 760 & 413 & 384 & 180 & 195 & 1,294 \\
\hline BAHAMAS & 61 & 184 & 109 & 117 & 49 & 50 & 295 \\
\hline BANGLADESH & 226 & 846 & 463 & 440 & 202 & 217 & 1,445 \\
\hline BELGIUM & 732 & 2,932 & 1,563 & 1,453 & 680 & 737 & 4,899 \\
\hline BRAZIL & 1,915 & 6,718 & 3,596 & 3,639 & 1,596 & 1,664 & 10,752 \\
\hline CAMBODIA & 101 & 367 & 205 & 197 & 90 & 98 & 645 \\
\hline CANADA & 46 & 175 & 99 & 95 & 45 & 49 & 319 \\
\hline CHILE & 715 & 2,361 & 1,358 & 1,349 & 600 & 629 & 3,995 \\
\hline CHINA MNLND & 21,292 & 77,988 & 43,448 & 41,807 & 19,167 & 20,773 & 137,523 \\
\hline CHINA TWN & 2,094 & 7,671 & 4,274 & 4,112 & 1,885 & 2,043 & 13,528 \\
\hline COLOMBIA & 365 & 1,121 & 656 & 688 & 295 & 301 & 1,823 \\
\hline COSTA RICA & 604 & 1,827 & 1,081 & 1,159 & 491 & 495 & 2,931 \\
\hline CZECH REP & 80 & 320 & 174 & 162 & 76 & 82 & 544 \\
\hline DENMARK & 173 & 688 & 371 & 345 & 161 & 175 & 1,162 \\
\hline DOM. REP & 318 & 1,057 & 568 & 599 & 256 & 261 & 1,570 \\
\hline ECUADOR & 385 & 1,254 & 728 & 732 & 324 & 337 & 2,106 \\
\hline EGYPT & 96 & 368 & 199 & 187 & 87 & 93 & 622 \\
\hline EL SALVADOR & 184 & 592 & 344 & 345 & 153 & 159 & 994 \\
\hline FINLAND & 125 & 491 & 266 & 248 & 116 & 126 & 837 \\
\hline FRANCE & 753 & 3,026 & 1,610 & 1,496 & 701 & 759 & 5,051 \\
\hline GERMANY & 1,916 & 7,630 & 4,145 & 3,859 & 1,804 & 1,953 & 12,990 \\
\hline GREECE & 86 & 335 & 180 & 169 & 78 & 85 & 564 \\
\hline GUATEMALA & 604 & 1,946 & 1,130 & 1,134 & 502 & 522 & 3,271 \\
\hline HAITI & 49 & 148 & 88 & 94 & 40 & 40 & 238 \\
\hline HONDURAS & 666 & 2,147 & 1,246 & 1,251 & 554 & 576 & 3,608 \\
\hline HONG KONG & 4,030 & 14,734 & 8,209 & 7,899 & 3,617 & 3,918 & 25,945 \\
\hline ICELAND & 18 & 74 & 39 & 36 & 17 & 19 & 123 \\
\hline INDIA & 1,171 & 4,418 & 2,403 & 2,276 & 1,050 & 1,132 & 7,528 \\
\hline INDONESIA & 1,045 & 3,808 & 2,122 & 2,042 & 933 & 1,009 & 6,665 \\
\hline IRELAND & 99 & 400 & 212 & 197 & 92 & 100 & 667 \\
\hline ISRAEL & 377 & 1,449 & 783 & 736 & 341 & 368 & 2,464 \\
\hline ITALY & 1,904 & 7,499 & 4,024 & 3,761 & 1,751 & 1,894 & 12,600 \\
\hline IVORY COAST & 35 & 134 & 72 & 69 & 31 & 34 & 223 \\
\hline JAMAICA & 45 & 137 & 81 & 87 & 37 & 37 & 220 \\
\hline JAPAN & 2,665 & 9,796 & 5,457 & 5,251 & 2,413 & 2,618 & 17,323 \\
\hline MALAYSIA & 949 & 3,458 & 1,927 & 1,854 & 847 & 916 & 6,072 \\
\hline MEXICO & 122 & 365 & 220 & 229 & 99 & 101 & 599 \\
\hline NETHERLANDS & 934 & 3,734 & 1,991 & 1,852 & 867 & 939 & 6,242 \\
\hline NEW ZEALAND & 271 & 952 & 530 & 519 & 237 & 254 & 1,676 \\
\hline NICARAGUA & 106 & 338 & 197 & 198 & 88 & 91 & 567 \\
\hline NORWAY & 81 & 322 & 173 & 161 & 75 & 82 & 543 \\
\hline OMAN & 18 & 70 & 38 & 36 & 17 & 18 & 119 \\
\hline PAKISTAN & 370 & 1,397 & 763 & 722 & 332 & 358 & 2,380 \\
\hline PANAMA & 64 & 194 & 115 & 120 & 52 & 53 & 322 \\
\hline PERU & 154 & 504 & 294 & 294 & 130 & 136 & 858 \\
\hline PHILIPPINES & 513 & 1,877 & 1,045 & 1,010 & 461 & 501 & 3,303 \\
\hline POLAND & 149 & 588 & 320 & 298 & 139 & 151 & 1,002 \\
\hline PORTUGAL & 131 & 535 & 284 & 263 & 124 & 134 & 891 \\
\hline RUSSIA & 135 & 532 & 288 & 269 & 125 & 135 & 901 \\
\hline SINGAPORE & 283 & 1,032 & 575 & 553 & 253 & 273 & 1,806 \\
\hline SOUTH AFRICA & 270 & 989 & 538 & 515 & 233 & 251 & 1,656 \\
\hline SOUTH KOREA & 1,800 & 6,572 & 3,679 & 3,540 & 1,625 & 1,762 & 11,603 \\
\hline SPAIN & 609 & 2,492 & 1,321 & 1,224 & 575 & 624 & 4,147 \\
\hline SRI LANKA & 163 & 614 & 335 & 317 & 146 & 157 & 1,046 \\
\hline SWEDEN & 288 & 1,148 & 618 & 576 & 269 & 291 & 1,954 \\
\hline SWITZERLAND & 78 & 309 & 168 & 156 & 73 & 79 & 525 \\
\hline THAILAND & 1,512 & 5,494 & 3,072 & 2,956 & 1,351 & 1,462 & 9,651 \\
\hline TRINIDAD & 22 & 76 & 42 & 43 & 19 & 19 & 117 \\
\hline TURKEY & 522 & 2,030 & 1,095 & 1,028 & 477 & 515 & 3,425 \\
\hline UNITED ARAB & 85 & 322 & 176 & 166 & 76 & 82 & 548 \\
\hline UK & 812 & 3,251 & 1,743 & 1,617 & 759 & 822 & 5,469 \\
\hline US VIRGIN IS & 25 & 76 & 45 & 49 & 21 & 21 & 123 \\
\hline VENEZUELA & 206 & 647 & 378 & 389 & 170 & 174 & 1,054 \\
\hline VIETNAM & 628 & 2,293 & 1,278 & 1,229 & 562 & 609 & 4,032 \\
\hline
\end{tabular}




\begin{tabular}{|c|c|c|c|c|c|c|c|}
\hline ORIGIN & 73 & 76 & 79 & 83 & 89 & 94 & 95 \\
\hline AMER. SAMOA & 72 & 52 & 127 & 475 & 120 & 50 & 10 \\
\hline ARGENTINA & 441 & 318 & 761 & 2,733 & 692 & 285 & 53 \\
\hline AUSTRALIA & 579 & 417 & 1,020 & 3,804 & 957 & 399 & 79 \\
\hline AUSTRIA & 361 & 258 & 598 & 2,153 & 544 & 221 & 40 \\
\hline BAHAMAS & 81 & 67 & 164 & 538 & 132 & 52 & 9 \\
\hline BANGLADESH & 409 & 290 & 686 & 2,511 & 658 & 275 & 55 \\
\hline BELGIUM & 1,376 & 976 & 2,261 & 8,125 & 2,051 & 833 & 150 \\
\hline BRAZIL & 3,016 & 2,243 & 5,429 & 18,887 & 4,750 & 1,923 & 342 \\
\hline CAMBODIA & 186 & 134 & 318 & 1,202 & 315 & 133 & 26 \\
\hline CANADA & 94 & 70 & 164 & 667 & 184 & 80 & 17 \\
\hline CHILE & 1,160 & 848 & 2,171 & 7,676 & 1,907 & 775 & 139 \\
\hline CHINA MNLND & 39,680 & 28,519 & 67,734 & 259,223 & 68,345 & 28,704 & 5,728 \\
\hline CHINA TWN & 3,903 & 2,805 & 6,663 & 25,499 & 6,723 & 2,824 & 563 \\
\hline COLOMBIA & 506 & 406 & 990 & 3,314 & 819 & 326 & 55 \\
\hline COSTA RICA & 808 & 667 & 1,632 & 5,345 & 1,308 & 516 & 85 \\
\hline CZECH REP & 152 & 108 & 252 & 905 & 229 & 93 & 17 \\
\hline DENMARK & 327 & 232 & 538 & 1,935 & 489 & 199 & 36 \\
\hline DOM. REP & 435 & 352 & 858 & 2,902 & 715 & 284 & 47 \\
\hline ECUADOR & 614 & 454 & 1,187 & 4,095 & 1,005 & 405 & 71 \\
\hline EGYPT & 176 & 124 & 291 & 1,054 & 268 & 110 & 20 \\
\hline EL SALVADOR & 290 & 214 & 560 & 1,954 & 479 & 193 & 34 \\
\hline FINLAND & 234 & 166 & 387 & 1,396 & 356 & 145 & 26 \\
\hline FRANCE & 1,418 & 1,005 & 2,327 & 8,357 & 2,108 & 855 & 154 \\
\hline GERMANY & 3,622 & 2,588 & 6,006 & 21,610 & 5,459 & 2,219 & 398 \\
\hline GREECE & 158 & 113 & 263 & 946 & 242 & 99 & 18 \\
\hline GUATEMALA & 954 & 704 & 1,839 & 6,418 & 1,576 & 636 & 111 \\
\hline HAITI & 66 & 54 & 133 & 434 & 106 & 42 & 7 \\
\hline HONDURAS & 1,052 & 777 & 2,029 & 7,081 & 1,738 & 702 & 123 \\
\hline HONG KONG & 7,481 & 5,371 & 12,765 & 48,491 & 12,821 & 5,380 & 1,072 \\
\hline ICELAND & 35 & 24 & 56 & 201 & 50 & 20 & 4 \\
\hline INDIA & 2,126 & 1,507 & 3,556 & 12,953 & 3,324 & 1,367 & 256 \\
\hline INDONESIA & 1,926 & 1,380 & 3,284 & 12,416 & 3,259 & 1,371 & 271 \\
\hline IRELAND & 185 & 133 & 306 & 1,089 & 277 & 112 & 20 \\
\hline ISRAEL & 692 & 490 & 1,149 & 4,161 & 1,058 & 435 & 80 \\
\hline ITALY & 3,524 & 2,516 & 5,859 & 20,990 & 5,353 & 2,181 & 394 \\
\hline IVORY COAST & 62 & 45 & 104 & 376 & 96 & 39 & 7 \\
\hline JAMAICA & 61 & 50 & 123 & 401 & 98 & 39 & 6 \\
\hline JAPAN & 5,005 & 3,605 & 8,550 & 32,921 & 8,707 & 3,663 & 733 \\
\hline MALAYSIA & 1,748 & 1,252 & 2,981 & 11,306 & 2,967 & 1,243 & 247 \\
\hline MEXICO & 177 & 136 & 384 & 1,271 & 293 & 115 & 19 \\
\hline NETHERLANDS & 1,739 & 1,243 & 2,882 & 10,280 & 2,616 & 1,063 & 190 \\
\hline NEW ZEALAND & 483 & 349 & 854 & 3,190 & 796 & 326 & 65 \\
\hline NICARAGUA & 165 & 122 & 322 & 1,118 & 274 & 110 & 19 \\
\hline NORWAY & 153 & 108 & 251 & 901 & 227 & 92 & 17 \\
\hline OMAN & 34 & 24 & 56 & 205 & 52 & 22 & 4 \\
\hline PAKISTAN & 672 & 478 & 1,129 & 4,110 & 1,051 & 432 & 81 \\
\hline PANAMA & 92 & 71 & 188 & 630 & 151 & 60 & 10 \\
\hline PERU & 250 & 183 & 474 & 1,651 & 408 & 165 & 29 \\
\hline PHILIPPINES & 952 & 686 & 1,625 & 6,195 & 1,630 & 684 & 136 \\
\hline POLAND & 280 & 200 & 465 & 1,674 & 423 & 172 & 31 \\
\hline PORTUGAL & 248 & 177 & 409 & 1,467 & 369 & 150 & 26 \\
\hline RUSSIA & 254 & 180 & 418 & 1,509 & 382 & 157 & 28 \\
\hline SINGAPORE & 522 & 374 & 890 & 3,367 & 884 & 372 & 74 \\
\hline SOUTH AFRICA & 467 & 334 & 794 & 2,858 & 733 & 301 & 56 \\
\hline SOUTH KOREA & 3,367 & 2,422 & 5,749 & 21,947 & 5,794 & 2,448 & 487 \\
\hline SPAIN & 1,152 & 824 & 1,902 & 6,820 & 1,717 & 695 & 123 \\
\hline SRI LANKA & 296 & 210 & 495 & 1,804 & 463 & 191 & 36 \\
\hline SWEDEN & 545 & 386 & 896 & 3,225 & 815 & 334 & 60 \\
\hline SWITZERLAND & 146 & 105 & 243 & 874 & 221 & 90 & 16 \\
\hline THAILAND & 2,779 & 1,999 & 4,757 & 17,989 & 4,722 & 1,987 & 393 \\
\hline TRINIDAD & 33 & 26 & 63 & 213 & 53 & 21 & 4 \\
\hline TURKEY & 961 & 681 & 1,593 & 5,764 & 1,473 & 602 & 110 \\
\hline UNITED ARAB & 155 & 110 & 260 & 943 & 242 & 99 & 19 \\
\hline UK & 1,520 & 1,078 & 2,491 & 8,939 & 2,272 & 921 & 163 \\
\hline US VIRGIN IS & 34 & 28 & 68 & 224 & 55 & 22 & 4 \\
\hline VENEZUELA & 293 & 234 & 571 & 1,915 & 474 & 189 & 32 \\
\hline VIETNAM & 1,162 & 833 & 1,981 & 7,505 & 1,980 & 830 & 165 \\
\hline
\end{tabular}




\begin{tabular}{|c|c|c|c|c|c|c|c|}
\hline ORIGIN & 96 & 104 & 105 & 107 & 108 & 111 & 112 \\
\hline AMER. SAMOA & 218 & 73 & 115 & 150 & 29 & 46 & 38 \\
\hline ARGENTINA & 1,171 & 397 & 603 & 876 & 164 & 264 & 235 \\
\hline AUSTRALIA & 1,735 & 583 & 916 & 1,201 & 235 & 365 & 306 \\
\hline AUSTRIA & 909 & 309 & 440 & 648 & 113 & 177 & 155 \\
\hline BAHAMAS & 210 & 72 & 115 & 188 & 34 & 59 & 67 \\
\hline BANGLADESH & 1,185 & 390 & 575 & 773 & 148 & 226 & 191 \\
\hline BELGIUM & 3,421 & 1,163 & 1,653 & 2,443 & 426 & 668 & 589 \\
\hline BRAZIL & 7,882 & 2,683 & 4,139 & 6,214 & 1,157 & 1,901 & 1,809 \\
\hline CAMBODIA & 573 & 188 & 276 & 370 & 71 & 108 & 90 \\
\hline CANADA & 393 & 115 & 153 & 193 & 37 & 49 & 42 \\
\hline CHILE & 3,161 & 1,108 & 1,702 & 2,593 & 484 & 784 & 733 \\
\hline CHINA MNLND & 125,314 & 40,822 & 59,836 & 79,375 & 15,213 & 22,932 & 19,195 \\
\hline CHINA TWN & 12,327 & 4,016 & 5,886 & 7,808 & 1,496 & 2,256 & 1,888 \\
\hline COLOMBIA & 1,323 & 453 & 714 & 1,172 & 215 & 364 & 389 \\
\hline COSTA RICA & 2,083 & 715 & 1,140 & 1,868 & 341 & 584 & 666 \\
\hline CZECH REP & 382 & 130 & 185 & 273 & 48 & 74 & 65 \\
\hline DENMARK & 817 & 278 & 396 & 583 & 102 & 158 & 140 \\
\hline DOM. REP & 1,133 & 388 & 613 & 999 & 183 & 305 & 329 \\
\hline ECUADOR & 1,659 & 589 & 913 & 1,440 & 267 & 437 & 428 \\
\hline EGYPT & 452 & 153 & 222 & 320 & 57 & 90 & 79 \\
\hline EL SALVADOR & 783 & 278 & 431 & 680 & 126 & 206 & 202 \\
\hline FINLAND & 594 & 202 & 291 & 422 & 75 & 116 & 102 \\
\hline FRANCE & 3,512 & 1,195 & 1,695 & 2,511 & 437 & 685 & 609 \\
\hline GERMANY & 9,120 & 3,101 & 4,412 & 6,506 & 1,138 & 1,773 & 1,558 \\
\hline GREECE & 407 & 137 & 198 & 287 & 51 & 81 & 71 \\
\hline GUATEMALA & 2,577 & 914 & 1,416 & 2,228 & 413 & 676 & 660 \\
\hline HAITI & 169 & 58 & 93 & 152 & 28 & 47 & 54 \\
\hline HONDURAS & 2,843 & 1,008 & 1,562 & 2,458 & 456 & 746 & 729 \\
\hline HONG KONG & 23,400 & 7,646 & 11,220 & 14,931 & 2,860 & 4,308 & 3,619 \\
\hline ICELAND & 83 & 28 & 40 & 60 & 10 & 16 & 14 \\
\hline INDIA & 5,638 & 1,910 & 2,788 & 3,962 & 722 & 1,144 & 985 \\
\hline INDONESIA & 5,921 & 1,938 & 2,861 & 3,828 & 732 & 1,132 & 949 \\
\hline IRELAND & 460 & 155 & 222 & 329 & 57 & 89 & 79 \\
\hline ISRAEL & 1,786 & 606 & 877 & 1,264 & 226 & 357 & 313 \\
\hline ITALY & 8,981 & 3,030 & 4,361 & 6,386 & 1,127 & 1,780 & 1,578 \\
\hline IVORY COAST & 161 & 54 & 79 & 114 & 21 & 34 & 31 \\
\hline JAMAICA & 156 & 54 & 86 & 140 & 26 & 44 & 50 \\
\hline JAPAN & 16,115 & 5,218 & 7,630 & 10,057 & 1,931 & 2,889 & 2,421 \\
\hline MALAYSIA & 5,366 & 1,764 & 2,594 & 3,474 & 664 & 1,013 & 849 \\
\hline MEXICO & 465 & 181 & 326 & 493 & 96 & 183 & 184 \\
\hline NETHERLANDS & 4,367 & 1,473 & 2,111 & 3,118 & 544 & 854 & 752 \\
\hline NEW ZEALAND & 1,413 & 488 & 774 & 1,009 & 198 & 307 & 258 \\
\hline NICARAGUA & 446 & 159 & 246 & 391 & 72 & 120 & 118 \\
\hline NORWAY & 379 & 129 & 183 & 271 & 47 & 73 & 65 \\
\hline OMAN & 89 & 30 & 44 & 63 & 11 & 18 & 16 \\
\hline PAKISTAN & 1,788 & 606 & 881 & 1,257 & 229 & 361 & 311 \\
\hline PANAMA & 245 & 89 & 140 & 235 & 42 & 72 & 77 \\
\hline PERU & 677 & 239 & 365 & 571 & 105 & 173 & 165 \\
\hline PHILIPPINES & 2,972 & 972 & 1,426 & 1,900 & 364 & 558 & 466 \\
\hline POLAND & 709 & 241 & 343 & 505 & 89 & 137 & 121 \\
\hline PORTUGAL & 614 & 209 & 295 & 440 & 76 & 119 & 107 \\
\hline RUSSIA & 640 & 217 & 313 & 455 & 80 & 124 & 110 \\
\hline SINGAPORE & 1,608 & 528 & 776 & 1,038 & 199 & 302 & 252 \\
\hline SOUTH AFRICA & 1,244 & 420 & 630 & 908 & 171 & 275 & 243 \\
\hline SOUTH KOREA & 10,724 & 3,466 & 5,074 & 6,748 & 1,294 & 1,935 & 1,629 \\
\hline SPAIN & 2,852 & 971 & 1,373 & 2,044 & 353 & 549 & 495 \\
\hline SRI LANKA & 787 & 266 & 389 & 552 & 101 & 160 & 137 \\
\hline SWEDEN & 1,361 & 463 & 664 & 971 & 170 & 263 & 234 \\
\hline SWITZERLAND & 369 & 125 & 178 & 263 & 46 & 72 & 63 \\
\hline THAILAND & 8,585 & 2,808 & 4,130 & 5,546 & 1,061 & 1,615 & 1,354 \\
\hline TRINIDAD & 86 & 29 & 46 & 72 & 13 & 22 & 22 \\
\hline TURKEY & 2,482 & 837 & 1,210 & 1,748 & 313 & 495 & 435 \\
\hline UNITED ARAB & 412 & 139 & 203 & 289 & 53 & 83 & 72 \\
\hline UK & 3,779 & 1,275 & 1,821 & 2,682 & 469 & 735 & 651 \\
\hline US VIRGIN IS & 87 & 30 & 48 & 78 & 14 & 24 & 28 \\
\hline VENEZUELA & 767 & 262 & 407 & 653 & 120 & 202 & 213 \\
\hline VIETNAM & 3,596 & 1,179 & 1,732 & 2,313 & 443 & 672 & 564 \\
\hline
\end{tabular}




\begin{tabular}{|c|c|c|c|c|c|c|c|}
\hline ORIGIN & 113 & 122 & 123 & 125 & 129 & 131 & 133 \\
\hline AMER. SAMOA & 139 & 299 & 69 & 362 & 75 & 33 & 61 \\
\hline ARGENTINA & 850 & 1,716 & 389 & 1,962 & 411 & 189 & 285 \\
\hline AUSTRALIA & 1,118 & 2,402 & 556 & 2,909 & 604 & 266 & 484 \\
\hline AUSTRIA & 565 & 1,123 & 253 & 1,268 & 266 & 122 & 182 \\
\hline BAHAMAS & 266 & 449 & 91 & 444 & 91 & 41 & 56 \\
\hline BANGLADESH & 682 & 1,460 & 340 & 1,768 & 367 & 164 & 288 \\
\hline BELGIUM & 2,145 & 4,255 & 955 & 4,792 & 1,005 & 460 & 689 \\
\hline BRAZIL & 6,683 & 12,902 & 2,842 & 14,183 & 2,973 & 1,345 & 1,972 \\
\hline CAMBODIA & 328 & 702 & 163 & 849 & 177 & 79 & 140 \\
\hline CANADA & 164 & 367 & 79 & 446 & 85 & 37 & 84 \\
\hline CHILE & 2,775 & 5,465 & 1,200 & 6,004 & 1,259 & 576 & 850 \\
\hline CHINA MNLND & 70,337 & 151,431 & 35,017 & 183,626 & 38,122 & 16,772 & 31,007 \\
\hline CHINA TWN & 6,919 & 14,896 & 3,445 & 18,063 & 3,750 & 1,650 & 3,050 \\
\hline COLOMBIA & 1,504 & 2,780 & 578 & 2,838 & 595 & 280 & 372 \\
\hline COSTA RICA & 2,641 & 4,458 & 905 & 4,411 & 905 & 409 & 553 \\
\hline CZECH REP & 237 & 472 & 106 & 533 & 112 & 51 & 76 \\
\hline DENMARK & 508 & 1,018 & 227 & 1,142 & 239 & 110 & 165 \\
\hline DOM. REP & 1,277 & 2,249 & 468 & 2,295 & 481 & 218 & 296 \\
\hline ECUADOR & 1,672 & 3,149 & 683 & 3,390 & 711 & 324 & 466 \\
\hline EGYPT & 286 & 576 & 131 & 659 & 138 & 63 & 96 \\
\hline EL SALVADOR & 789 & 1,507 & 322 & 1,600 & 335 & 153 & 225 \\
\hline FINLAND & 371 & 743 & 168 & 844 & 176 & 81 & 122 \\
\hline FRANCE & 2,204 & 4,366 & 978 & 4,909 & 1,029 & 471 & 705 \\
\hline GERMANY & 5,667 & 11,275 & 2,534 & 12,729 & 2,669 & 1,223 & 1,823 \\
\hline GREECE & 258 & 518 & 117 & 591 & 123 & 57 & 86 \\
\hline GUATEMALA & 2,571 & 4,922 & 1,054 & 5,239 & 1,098 & 501 & 774 \\
\hline HAITI & 214 & 362 & 74 & 358 & 73 & 33 & 45 \\
\hline HONDURAS & 2,837 & 5,430 & 1,163 & 5,780 & 1,212 & 552 & 854 \\
\hline HONG KONG & 13,221 & 28,419 & 6,579 & 34,419 & 7,151 & 3,145 & 5,736 \\
\hline ICELAND & 49 & 97 & 21 & 110 & 23 & 10 & 15 \\
\hline INDIA & 3,518 & 7,233 & 1,653 & 8,388 & 1,752 & 806 & 1,239 \\
\hline INDONESIA & 3,449 & 7,394 & 1,715 & 8,937 & 1,859 & 827 & 1,470 \\
\hline IRELAND & 287 & 566 & 127 & 640 & 132 & 61 & 90 \\
\hline ISRAEL & 1,128 & 2,291 & 518 & 2,608 & 547 & 251 & 381 \\
\hline ITALY & 5,723 & 11,444 & 2,581 & 12,980 & 2,704 & 1,240 & 1,869 \\
\hline IVORY COAST & 113 & 227 & 51 & 255 & 54 & 25 & 37 \\
\hline JAMAICA & 198 & 335 & 68 & 331 & 68 & 31 & 42 \\
\hline JAPAN & 8,926 & 19,277 & 4,447 & 23,433 & 4,857 & 2,120 & 4,025 \\
\hline MALAYSIA & 3,071 & 6,581 & 1,533 & 7,982 & 1,655 & 737 & 1,310 \\
\hline MEXICO & 848 & 1,957 & 358 & 1,637 & 355 & 176 & 196 \\
\hline NETHERLANDS & 2,736 & 5,434 & 1,220 & 6,124 & 1,284 & 584 & 875 \\
\hline NEW ZEALAND & 946 & 2,037 & 471 & 2,470 & 513 & 224 & 415 \\
\hline NICARAGUA & 462 & 876 & 186 & 936 & 194 & 88 & 126 \\
\hline NORWAY & 236 & 468 & 105 & 528 & 111 & 51 & 75 \\
\hline OMAN & 56 & 114 & 26 & 132 & 28 & 13 & 19 \\
\hline PAKISTAN & 1,116 & 2,286 & 524 & 2,650 & 556 & 254 & 391 \\
\hline PANAMA & 308 & 564 & 117 & 571 & 120 & 56 & 74 \\
\hline PERU & 634 & 1,217 & 267 & 1,331 & 279 & 127 & 184 \\
\hline PHILIPPINES & 1,704 & 3,661 & 848 & 4,434 & 921 & 407 & 742 \\
\hline POLAND & 440 & 878 & 198 & 993 & 208 & 95 & 143 \\
\hline PORTUGAL & 393 & 774 & 173 & 866 & 180 & 83 & 123 \\
\hline RUSSIA & 397 & 799 & 179 & 906 & 189 & 87 & 130 \\
\hline SINGAPORE & 918 & 1,968 & 458 & 2,388 & 495 & 220 & 393 \\
\hline SOUTH AFRICA & 869 & 1,773 & 402 & 2,031 & 426 & 196 & 299 \\
\hline SOUTH KOREA & 5,953 & 12,833 & 2,980 & 15,660 & 3,232 & 1,417 & 2,649 \\
\hline SPAIN & 1,810 & 3,567 & 797 & 3,993 & 837 & 383 & 571 \\
\hline SRI LANKA & 490 & 1,009 & 231 & 1,172 & 245 & 113 & 178 \\
\hline SWEDEN & 846 & 1,696 & 379 & 1,914 & 399 & 183 & 274 \\
\hline SWITZERLAND & 229 & 456 & 103 & 515 & 108 & 49 & 74 \\
\hline THAILAND & 4,904 & 10,515 & 2,439 & 12,709 & 2,644 & 1,176 & 2,098 \\
\hline TRINIDAD & 85 & 158 & 33 & 164 & 34 & 16 & 22 \\
\hline TURKEY & 1,562 & 3,165 & 714 & 3,614 & 753 & 346 & 524 \\
\hline UNITED ARAB & 257 & 526 & 121 & 610 & 127 & 59 & 90 \\
\hline UK & 2,375 & 4,691 & 1,049 & 5,263 & 1,095 & 501 & 748 \\
\hline US VIRGIN IS & 111 & 187 & 38 & 185 & 38 & 17 & 23 \\
\hline VENEZUELA & 801 & 1,469 & 309 & 1,520 & 319 & 150 & 202 \\
\hline VIETNAM & 2,046 & 4,409 & 1,018 & 5,311 & 1,109 & 490 & 881 \\
\hline
\end{tabular}




\begin{tabular}{|c|c|c|c|c|c|c|c|}
\hline ORIGIN & 137 & 138 & 139 & 143 & 146 & 152 & 153 \\
\hline AMER. SAMOA & 81 & 71 & 40 & 77 & 27 & 29 & 34 \\
\hline ARGENTINA & 402 & 385 & 200 & 379 & 131 & 135 & 131 \\
\hline AUSTRALIA & 644 & 564 & 322 & 615 & 214 & 231 & 271 \\
\hline AUSTRIA & 266 & 262 & 139 & 281 & 96 & 101 & 94 \\
\hline BAHAMAS & 77 & 79 & 35 & 65 & 20 & 21 & 17 \\
\hline BANGLADESH & 390 & 348 & 201 & 395 & 145 & 157 & 179 \\
\hline BELGIUM & 997 & 992 & 526 & 1,062 & 363 & 379 & 354 \\
\hline BRAZIL & 2,762 & 2,709 & 1,343 & 2,512 & 838 & 860 & 794 \\
\hline CAMBODIA & 188 & 166 & 97 & 191 & 70 & 76 & 89 \\
\hline CANADA & 105 & 82 & 59 & 125 & 54 & 70 & 165 \\
\hline CHILE & 1,193 & 1,164 & 583 & 1,067 & 356 & 351 & 340 \\
\hline CHINA MNLND & 40,932 & 35,619 & 21,110 & 41,986 & 15,536 & 17,005 & 20,505 \\
\hline CHINA TWN & 4,026 & 3,504 & 2,077 & 4,130 & 1,528 & 1,673 & 2,017 \\
\hline COLOMBIA & 506 & 508 & 237 & 419 & 134 & 134 & 117 \\
\hline COSTA RICA & 761 & 789 & 352 & 644 & 201 & 204 & 172 \\
\hline CZECH REP & 112 & 110 & 59 & 118 & 40 & 42 & 40 \\
\hline DENMARK & 240 & 238 & 126 & 254 & 87 & 91 & 86 \\
\hline DOM. REP & 409 & 425 & 192 & 353 & 112 & 114 & 98 \\
\hline ECUADOR & 643 & 646 & 313 & 564 & 184 & 178 & 169 \\
\hline EGYPT & 137 & 134 & 72 & 143 & 50 & 52 & 50 \\
\hline EL SALVADOR & 307 & 305 & 148 & 266 & 87 & 84 & 102 \\
\hline FINLAND & 178 & 174 & 93 & 186 & 64 & 67 & 64 \\
\hline FRANCE & 1,020 & 1,017 & 539 & 1,089 & 372 & 388 & 362 \\
\hline GERMANY & 2,670 & 2,634 & 1,398 & 2,818 & 966 & 1,014 & 947 \\
\hline GREECE & 122 & 119 & 64 & 127 & 44 & 46 & 44 \\
\hline GUATEMALA & 1,008 & 1,000 & 485 & 876 & 286 & 278 & 349 \\
\hline HAITI & 62 & 64 & 29 & 52 & 16 & 17 & 14 \\
\hline HONDURAS & 1,112 & 1,103 & 535 & 966 & 315 & 306 & 385 \\
\hline HONG KONG & 7,660 & 6,700 & 3,949 & 7,830 & 2,892 & 3,152 & 3,752 \\
\hline ICELAND & 24 & 24 & 12 & 25 & 9 & 9 & 8 \\
\hline INDIA & 1,768 & 1,693 & 917 & 1,805 & 635 & 663 & 742 \\
\hline INDONESIA & 1,983 & 1,750 & 1,002 & 1,976 & 728 & 787 & 916 \\
\hline IRELAND & 133 & 132 & 70 & 141 & 48 & 51 & 47 \\
\hline ISRAEL & 541 & 528 & 284 & 564 & 196 & 205 & 198 \\
\hline ITALY & 2,665 & 2,613 & 1,393 & 2,794 & 963 & 1,010 & 954 \\
\hline IVORY COAST & 52 & 50 & 26 & 50 & 17 & 18 & 17 \\
\hline JAMAICA & 57 & 59 & 26 & 48 & 15 & 15 & 13 \\
\hline JAPAN & 5,241 & 4,513 & 2,705 & 5,414 & 2,011 & 2,235 & 2,751 \\
\hline MALAYSIA & 1,764 & 1,565 & 909 & 1,791 & 659 & 712 & 828 \\
\hline MEXICO & 258 & 259 & 114 & 192 & 55 & 49 & 45 \\
\hline NETHERLANDS & 1,274 & 1,259 & 668 & 1,347 & 461 & 484 & 451 \\
\hline NEW ZEALAND & 548 & 479 & 273 & 514 & 174 & 190 & 224 \\
\hline NICARAGUA & 176 & 176 & 84 & 152 & 49 & 48 & 52 \\
\hline NORWAY & 111 & 110 & 58 & 118 & 40 & 42 & 39 \\
\hline OMAN & 28 & 27 & 14 & 29 & 10 & 10 & 10 \\
\hline PAKISTAN & 558 & 535 & 290 & 570 & 201 & 210 & 207 \\
\hline PANAMA & 101 & 100 & 47 & 83 & 26 & 25 & 23 \\
\hline PERU & 258 & 256 & 125 & 227 & 76 & 74 & 71 \\
\hline PHILIPPINES & 986 & 863 & 502 & 994 & 367 & 401 & 474 \\
\hline POLAND & 209 & 205 & 109 & 220 & 75 & 79 & 74 \\
\hline PORTUGAL & 177 & 176 & 93 & 188 & 64 & 67 & 62 \\
\hline RUSSIA & 189 & 187 & 100 & 200 & 69 & 72 & 68 \\
\hline SINGAPORE & 528 & 466 & 272 & 537 & 198 & 214 & 250 \\
\hline SOUTH AFRICA & 422 & 402 & 211 & 398 & 138 & 145 & 142 \\
\hline SOUTH KOREA & 3,477 & 3,028 & 1,804 & 3,577 & 1,333 & 1,465 & 1,788 \\
\hline SPAIN & 820 & 815 & 431 & 873 & 297 & 312 & 287 \\
\hline SRI LANKA & 247 & 237 & 128 & 252 & 90 & 97 & 111 \\
\hline SWEDEN & 399 & 396 & 210 & 424 & 145 & 152 & 142 \\
\hline SWITZERLAND & 108 & 107 & 57 & 114 & 39 & 41 & 38 \\
\hline THAILAND & 2,820 & 2,489 & 1,453 & 2,855 & 1,055 & 1,142 & 1,331 \\
\hline TRINIDAD & 31 & 31 & 15 & 27 & 9 & 9 & 8 \\
\hline TURKEY & 748 & 728 & 390 & 778 & 270 & 283 & 271 \\
\hline UNITED ARAB & 129 & 123 & 67 & 131 & 46 & 48 & 48 \\
\hline UK & 1,091 & 1,083 & 573 & 1,159 & 395 & 415 & 383 \\
\hline US VIRGIN IS & 32 & 33 & 15 & 27 & 8 & 9 & 7 \\
\hline VENEZUELA & 275 & 279 & 130 & 237 & 76 & 78 & 68 \\
\hline VIETNAM & 1,180 & 1,038 & 608 & 1,201 & 443 & 480 & 564 \\
\hline
\end{tabular}




\begin{tabular}{|c|c|c|c|c|c|c|c|}
\hline ORIGIN & 157 & 160 & 162 & 163 & 165 & 167 & 171 \\
\hline AMER. SAMOA & 234 & 52 & 216 & 126 & 104 & 89 & 253 \\
\hline ARGENTINA & 1,096 & 229 & 858 & 456 & 398 & 303 & 818 \\
\hline AUSTRALIA & 1,863 & 414 & 1,729 & 995 & 830 & 698 & 1,988 \\
\hline AUSTRIA & 735 & 143 & 535 & 276 & 260 & 201 & 548 \\
\hline BAHAMAS & 179 & 38 & 131 & 53 & 53 & 37 & 95 \\
\hline BANGLADESH & 1,222 & 247 & 1,010 & 596 & 533 & 458 & 1,293 \\
\hline BELGIUM & 2,767 & 538 & 2,004 & 1,025 & 969 & 746 & 2,039 \\
\hline BRAZIL & 7,191 & 1,506 & 5,464 & 2,524 & 2,412 & 1,780 & 4,650 \\
\hline CAMBODIA & 595 & 120 & 495 & 295 & 262 & 228 & 649 \\
\hline CANADA & 555 & 75 & 359 & 329 & 339 & 1,015 & 13,198 \\
\hline CHILE & 3,110 & 656 & 2,430 & 1,367 & 1,142 & 823 & 2,323 \\
\hline CHINA MNLND & 132,869 & 26,418 & 111,069 & 67,664 & 60,384 & 54,195 & 156,365 \\
\hline CHINA TWN & 13,070 & 2,599 & 10,925 & 6,656 & 5,940 & 5,331 & 15,381 \\
\hline COLOMBIA & 1,230 & 262 & 907 & 385 & 371 & 264 & 676 \\
\hline COSTA RICA & 1,778 & 381 & 1,297 & 531 & 526 & 370 & 944 \\
\hline CZECH REP & 309 & 60 & 225 & 116 & 109 & 84 & 231 \\
\hline DENMARK & 667 & 130 & 482 & 249 & 235 & 181 & 495 \\
\hline DOM. REP & 995 & 209 & 734 & 305 & 300 & 213 & 552 \\
\hline ECUADOR & 1,639 & 344 & 1,240 & 686 & 568 & 402 & 1,144 \\
\hline EGYPT & 383 & 77 & 290 & 150 & 140 & 109 & 295 \\
\hline EL SALVADOR & 781 & 193 & 882 & 492 & 395 & 267 & 771 \\
\hline FINLAND & 494 & 97 & 361 & 189 & 177 & 137 & 375 \\
\hline FRANCE & 2,828 & 553 & 2,043 & 1,043 & 993 & 764 & 2,076 \\
\hline GERMANY & 7,376 & 1,438 & 5,366 & 2,768 & 2,613 & 2,013 & 5,504 \\
\hline GREECE & 340 & 68 & 255 & 131 & 123 & 95 & 261 \\
\hline GUATEMALA & 2,705 & 663 & 3,039 & 1,720 & 1,357 & 917 & 2,646 \\
\hline HAITI & 144 & 31 & 105 & 43 & 43 & 30 & 77 \\
\hline HONDURAS & 2,984 & 732 & 3,353 & 1,898 & 1,497 & 1,011 & 2,919 \\
\hline HONG KONG & 24,614 & 4,913 & 20,533 & 12,404 & 11,076 & 9,825 & 28,181 \\
\hline ICELAND & 65 & 12 & 45 & 23 & 22 & 17 & 46 \\
\hline INDIA & 5,058 & 1,021 & 4,180 & 2,475 & 2,205 & 1,894 & 5,347 \\
\hline INDONESIA & 6,140 & 1,259 & 5,212 & 3,093 & 2,716 & 2,351 & 6,674 \\
\hline IRELAND & 365 & 71 & 261 & 134 & 127 & 98 & 268 \\
\hline ISRAEL & 1,520 & 306 & 1,151 & 596 & 557 & 432 & 1,177 \\
\hline ITALY & 7,395 & 1,483 & 5,524 & 2,822 & 2,653 & 2,051 & 5,607 \\
\hline IVORY COAST & 140 & 29 & 109 & 53 & 50 & 38 & 103 \\
\hline JAMAICA & 134 & 29 & 97 & 40 & 39 & 28 & 71 \\
\hline JAPAN & 17,371 & 3,426 & 14,584 & 9,044 & 8,061 & 7,421 & 21,696 \\
\hline MALAYSIA & 5,557 & 1,122 & 4,617 & 2,745 & 2,454 & 2,130 & 6,044 \\
\hline MEXICO & 553 & 120 & 395 & 146 & 146 & 101 & 254 \\
\hline NETHERLANDS & 3,516 & 689 & 2,552 & 1,314 & 1,242 & 956 & 2,614 \\
\hline NEW ZEALAND & 1,577 & 356 & 1,496 & 850 & 713 & 581 & 1,652 \\
\hline NICARAGUA & 441 & 98 & 442 & 250 & 202 & 138 & 392 \\
\hline NORWAY & 307 & 59 & 220 & 114 & 108 & 83 & 226 \\
\hline OMAN & 78 & 16 & 60 & 32 & 29 & 23 & 66 \\
\hline PAKISTAN & 1,575 & 320 & 1,218 & 660 & 594 & 501 & 1,409 \\
\hline PANAMA & 244 & 52 & 179 & 76 & 73 & 52 & 132 \\
\hline PERU & 668 & 140 & 514 & 290 & 242 & 173 & 490 \\
\hline PHILIPPINES & 3,135 & 632 & 2,640 & 1,585 & 1,401 & 1,239 & 3,548 \\
\hline POLAND & 578 & 113 & 422 & 218 & 206 & 159 & 434 \\
\hline PORTUGAL & 485 & 96 & 353 & 178 & 169 & 130 & 355 \\
\hline RUSSIA & 528 & 103 & 385 & 201 & 189 & 146 & 397 \\
\hline SINGAPORE & 1,670 & 337 & 1,389 & 828 & 740 & 642 & 1,834 \\
\hline SOUTH AFRICA & 1,154 & 242 & 912 & 460 & 426 & 326 & 871 \\
\hline SOUTH KOREA & 11,454 & 2,269 & 9,535 & 5,852 & 5,219 & 4,733 & 13,729 \\
\hline SPAIN & 2,253 & 442 & 1,638 & 827 & 785 & 603 & 1,647 \\
\hline SRI LANKA & 754 & 152 & 625 & 369 & 329 & 282 & 797 \\
\hline SWEDEN & 1,109 & 216 & 802 & 416 & 393 & 303 & 823 \\
\hline SWITZERLAND & 298 & 58 & 217 & 112 & 106 & 81 & 223 \\
\hline THAILAND & 8,911 & 1,797 & 7,408 & 4,415 & 3,928 & 3,419 & 9,714 \\
\hline TRINIDAD & 76 & 16 & 57 & 25 & 24 & 17 & 45 \\
\hline TURKEY & 2,085 & 420 & 1,573 & 811 & 759 & 589 & 1,611 \\
\hline UNITED ARAB & 363 & 74 & 281 & 148 & 137 & 109 & 305 \\
\hline UK & 3,001 & 586 & 2,160 & 1,107 & 1,049 & 806 & 2,204 \\
\hline US VIRGIN IS & 74 & 16 & 54 & 22 & 22 & 15 & 39 \\
\hline VENEZUELA & 678 & 144 & 503 & 214 & 208 & 149 & 385 \\
\hline VIETNAM & 3,750 & 755 & 3,122 & 1,869 & 1,670 & 1,463 & 4,172 \\
\hline
\end{tabular}




\begin{tabular}{|c|c|c|c|c|c|c|c|}
\hline ORIGIN & 172 & 176 & 177 & 178 & 179 & 180 & 181 \\
\hline AMER. SAMOA & 178 & 639 & 11 & 126 & 53 & 970 & 178 \\
\hline ARGENTINA & 583 & 2,210 & 39 & 434 & 191 & 3,610 & 671 \\
\hline AUSTRALIA & 1,396 & 5,037 & 89 & 989 & 419 & 7,735 & 1,420 \\
\hline AUSTRIA & 377 & 1,263 & 23 & 249 & 109 & 2,067 & 376 \\
\hline BAHAMAS & 65 & 254 & 4 & 51 & 24 & 458 & 85 \\
\hline BANGLADESH & 891 & 2,987 & 55 & 588 & 250 & 4,451 & 806 \\
\hline BELGIUM & 1,401 & 4,688 & 85 & 926 & 407 & 7,729 & 1,405 \\
\hline BRAZIL & 3,191 & 12,130 & 212 & 2,395 & 1,082 & 20,726 & 3,780 \\
\hline CAMBODIA & 447 & 1,483 & 27 & 291 & 124 & 2,201 & 397 \\
\hline CANADA & 2,163 & 2,034 & 49 & 386 & 149 & 2,182 & 392 \\
\hline CHILE & 1,669 & 6,619 & 115 & 1,297 & 584 & 11,241 & 2,140 \\
\hline CHINA MNLND & 107,188 & 345,930 & 6,366 & 67,872 & 28,678 & 501,242 & 91,175 \\
\hline CHINA TWN & 10,544 & 34,028 & 626 & 6,676 & 2,821 & 49,305 & 8,969 \\
\hline COLOMBIA & 461 & 1,885 & 32 & 369 & 167 & 3,265 & 635 \\
\hline COSTA RICA & 643 & 2,524 & 43 & 504 & 234 & 4,547 & 847 \\
\hline CZECH REP & 158 & 531 & 10 & 105 & 46 & 869 & 158 \\
\hline DENMARK & 340 & 1,141 & 21 & 225 & 98 & 1,867 & 339 \\
\hline DOM. REP & 377 & 1,466 & 25 & 289 & 134 & 2,612 & 480 \\
\hline ECUADOR & 829 & 3,392 & 57 & 663 & 300 & 5,843 & 1,132 \\
\hline EGYPT & 204 & 691 & 12 & 136 & 60 & 1,136 & 206 \\
\hline EL SALVADOR & 567 & 2,462 & 40 & 480 & 221 & 4,440 & 893 \\
\hline FINLAND & 257 & 868 & 16 & 171 & 75 & 1,409 & 257 \\
\hline FRANCE & 1,426 & 4,793 & 86 & 941 & 414 & 7,867 & 1,430 \\
\hline GERMANY & 3,783 & 12,673 & 229 & 2,502 & 1,095 & 20,749 & 3,771 \\
\hline GREECE & 180 & 606 & 11 & 120 & 53 & 999 & 182 \\
\hline GUATEMALA & 1,947 & 8,497 & 138 & 1,655 & 765 & 15,376 & 3,103 \\
\hline HAITI & 52 & 205 & 4 & 41 & 19 & 369 & 69 \\
\hline HONDURAS & 2,148 & 9,374 & 152 & 1,825 & 844 & 16,963 & 3,423 \\
\hline HONG KONG & 19,347 & 63,018 & 1,160 & 12,372 & 5,238 & 91,997 & 16,714 \\
\hline ICELAND & 32 & 106 & 2 & 21 & 9 & 169 & 30 \\
\hline INDIA & 3,686 & 12,357 & 227 & 2,430 & 1,034 & 18,416 & 3,335 \\
\hline INDONESIA & 4,616 & 15,554 & 282 & 3,057 & 1,298 & 23,083 & 4,186 \\
\hline IRELAND & 184 & 613 & 11 & 121 & 53 & 1,002 & 183 \\
\hline ISRAEL & 811 & 2,756 & 50 & 544 & 240 & 4,526 & 821 \\
\hline ITALY & 3,858 & 12,971 & 235 & 2,561 & 1,136 & 21,481 & 3,921 \\
\hline IVORY COAST & 71 & 255 & 5 & 50 & 22 & 425 & 77 \\
\hline JAMAICA & 48 & 190 & 3 & 38 & 18 & 341 & 64 \\
\hline JAPAN & 14,822 & 46,872 & 861 & 9,183 & 3,864 & 66,827 & 12,187 \\
\hline MALAYSIA & 4,161 & 13,846 & 254 & 2,722 & 1,151 & 20,494 & 3,715 \\
\hline MEXICO & 173 & 702 & 12 & 139 & 66 & 1,313 & 243 \\
\hline NETHERLANDS & 1,797 & 6,013 & 108 & 1,187 & 522 & 9,853 & 1,801 \\
\hline NEW ZEALAND & 1,168 & 4,331 & 76 & 850 & 359 & 6,757 & 1,244 \\
\hline NICARAGUA & 290 & 1,232 & 20 & 243 & 110 & 2,200 & 439 \\
\hline NORWAY & 155 & 523 & 9 & 103 & 45 & 852 & 155 \\
\hline OMAN & 45 & 153 & 3 & 30 & 13 & 242 & 44 \\
\hline PAKISTAN & 972 & 3,279 & 60 & 645 & 275 & 4,915 & 889 \\
\hline PANAMA & 91 & 377 & 6 & 74 & 33 & 656 & 128 \\
\hline PERU & 351 & 1,415 & 24 & 277 & 125 & 2,412 & 463 \\
\hline PHILIPPINES & 2,437 & 8,044 & 147 & 1,579 & 669 & 11,820 & 2,147 \\
\hline POLAND & 299 & 1,002 & 18 & 198 & 86 & 1,637 & 297 \\
\hline PORTUGAL & 244 & 813 & 15 & 161 & 71 & 1,354 & 248 \\
\hline RUSSIA & 273 & 922 & 17 & 182 & 79 & 1,498 & 272 \\
\hline SINGAPORE & 1,256 & 4,167 & 77 & 819 & 348 & 6,180 & 1,116 \\
\hline SOUTH AFRICA & 601 & 2,201 & 39 & 435 & 192 & 3,610 & 654 \\
\hline SOUTH KOREA & 9,398 & 30,293 & 553 & 5,940 & 2,488 & 43,584 & 7,885 \\
\hline SPAIN & 1,131 & 3,770 & 68 & 744 & 330 & 6,278 & 1,142 \\
\hline SRI LANKA & 550 & 1,842 & 34 & 362 & 154 & 2,746 & 497 \\
\hline SWEDEN & 566 & 1,906 & 34 & 376 & 164 & 3,104 & 564 \\
\hline SWITZERLAND & 153 & 513 & 9 & 101 & 44 & 839 & 152 \\
\hline THAILAND & 6,686 & 22,202 & 407 & 4,364 & 1,853 & 32,950 & 5,948 \\
\hline TRINIDAD & 31 & 118 & 2 & 23 & 11 & 207 & 38 \\
\hline TURKEY & 1,109 & 3,746 & 68 & 740 & 327 & 6,166 & 1,119 \\
\hline UNITED ARAB & 211 & 712 & 13 & 140 & 60 & 1,121 & 204 \\
\hline UK & 1,513 & 5,050 & 91 & 997 & 439 & 8,299 & 1,519 \\
\hline US VIRGIN IS & 27 & 106 & 2 & 21 & 10 & 190 & 35 \\
\hline VENEZUELA & 263 & 1,020 & 18 & 201 & 93 & 1,806 & 331 \\
\hline VIETNAM & 2,869 & 9,433 & 174 & 1,853 & 786 & 13,946 & 2,531 \\
\hline
\end{tabular}




\section{REFERENCES}

Asian Economic News, Hong Kong Port Throughput Slips to $3^{\text {rd }}$ after Singapore, Shanghai: A Report, April 23, 2007.

B. Ashtakala and A.S.N. Murthy (1988). "Optimized gravity models for commodity transportation”, Journal of Transportation Engineering, ASCE, 114, 393-408.

B. Ashtakala and A.S.N. Murthy (1993). "Sequential models to determine intercity commodity transportation demand”, Transportation Research Part A, 27, 373-382.

W.R. Black (1971). "The utility of the gravity model and estimates of its parameters in commodity flow studies”, Proceedings of the Association of American Geographers, 3, 28-32.

M. Chisholm and P. O’Sullivan (1973). Freight flows and spatial aspects of the British economy, Cambridge University Press, London.

Intermodal Association of North America (2007). Intermodal Industry Statistics, accessed online at http://www.intermodal.org/statistics_files/stats5.shtml on 8/3/2007.

R.C. Leachman (2005). Final Report: Port and Modal Elasticity Study, prepared for Southern California Association of Governments, Piedmont, California, September.

Pacific Maritime Association (2007). Research Reports, accessed on line at http://www.pmanet.org/hours_data/index.cfm?app=selectCo on 8/24/2007.

U.S. Maritime Administration (2007). Data and Statistics, accessed on line at http://www.marad.dot.gov/MARAD statistics/index.html on 8/24/2007.

Waterborne Databank (2004) available from the U.S. Maritime Administration, Washington D.C.

U.S. Department of Commerce, Bureau of Economic Analysis (2004). Regional Economic Accounts, accessed on-line at http://www.bea.gov/bea/regional/reis/ on 8/27/07.

World Bank (2006). Data and Statistics, accessed on line at http://web.worldbank.org/ on $8 / 27 / 07$.

K. E. Wolfe and W. P. Linde (1997). The Carload Waybill Statistics: Usefulness for Economic Analysis, Journal of the Transportation Analysis Forum, 36 (2), 26-41. 